\title{
Improved age control on early Homo fossils from the upper Burgi Member at Koobi
}

\section{Fora, Kenya}

Josephine C.A. Joordens ${ }^{\mathrm{a}, \mathrm{j}^{*}}$, Guillaume Dupont-Nivet ${ }^{\mathrm{b}, \mathrm{c}}$, Craig S. Feibel $^{\mathrm{d}}$, Fred Spoor ${ }^{\mathrm{e}, \mathrm{f}}$, Mark J. Sier ${ }^{\mathrm{a}, \mathrm{c}, \mathrm{g}}$, Jeroen H.J.L. van der Lubbe ${ }^{\mathrm{h}}$, Trine Kellberg Nielsen ${ }^{\mathrm{a}, \mathrm{i}}$, Monika V. Knul ${ }^{\mathrm{a}}$, Gareth R. Davies ${ }^{\mathrm{j}}$, Hubert B. Vonhof

${ }^{\text {a }}$ Faculty of Archaeology, Leiden University, P.O. Box 9515, 2300 RA Leiden, The Netherlands

${ }^{\mathrm{b}}$ Geosciences Rennes UMR-CNRS 6118, 263 Avenue du General Leclerc, 350042 Rennes Cedex, France

${ }^{\mathrm{c}}$ Faculty of Geosciences, Utrecht University, P.O. Box 80021, 3508 TA Utrecht, The Netherlands

${ }^{\mathrm{d}}$ Depts. of Geology and Anthropology, Rutgers University, 610 Taylor Road, Piscataway NJ, USA

${ }^{\mathrm{e}}$ Dept. of Human Evolution, Max Planck Institute for Evolutionary Anthropology, Deutscher Platz 6, D-04103 Leipzig, Germany

${ }^{\mathrm{f}}$ Dept. of Cell \& Developmental Biology, University College London, London WC1E 6BT, UK

${ }^{\mathrm{g}}$ National Research Center for Human Evolution, Paseo Sierra de Atapuerca s/n, Burgos, Spain

${ }^{\mathrm{h}}$ Institute of Geosciences, University of Kiel, Ludewig-Meyn-Str. 10, D-24118 Kiel, Germany

${ }^{i}$ Prehistoric Archaeology, Aarhus University, Moesgård Allé 20, 8270 Højbjerg, Denmark

${ }^{\mathrm{j}}$ Faculty of Earth and Life Sciences, VU University Amsterdam, De Boelelaan 1085, $1081 \mathrm{HV}$ Amsterdam, The Netherlands

Key words

Turkana Basin, magnetostratigraphy, Olduvai chron, Pre-Olduvai event, strontium isotope ratios, precession, eccentricity, climate, source area

\begin{abstract}
To address questions regarding the evolutionary origin, radiation and dispersal of the genus Homo it is crucial to be able to place the occurrence of hominin fossils in a high-resolution chronological framework. The period around $2 \mathrm{Ma}$ in eastern Africa is of particular interest in
\end{abstract}


this context as it is at this time that a more substantial fossil record of the genus Homo is first found. Here we apply a novel approach, combining magnetostratigraphy and strontium (Sr) isotope stratigraphy, to improve age control on hominin-bearing upper Burgi (UBU) deposits in Areas 105 and 131 on the Karari Ridge in the eastern Turkana Basin (Kenya). We identify the base of the Olduvai subchron (bC2n) plus a short isolated interval of consistently normal polarity directions that we interpret to be the Pre-Olduvai event. Combined with precessionforced ( $20 \mathrm{kyr}$ ) wet-dry climate cycles resolved by $\mathrm{Sr}$ isotope ratios, the magnetostratigraphic data allow us to construct an age model for these UBU deposits. Hence, we provide detailed age constraints for 15 hominin fossils from Area 131, showing that key specimens such as cranium KNM-ER 1470, partial face KNM-ER 62000 and mandibles KNM-ER 1482, KNMER 1801, and KNM-ER 1802 can be constrained between $1.945 \pm 0.004$ and $2.058 \pm 0.034$ Ma, and thus older than previously estimated. The new ages are consistent with a temporal overlap of two species of early Homo that can be distinguished by their facial morphology. Further, our results show that in this time interval, hominins occurred throughout the wet-dry climate cycles, supporting the hypothesis that the lacustrine Turkana Basin was a refugium during regionally dry periods. By establishing the observed first appearance datum of a marine-derived stingray in UBU deposits at $2.058 \pm 0.034 \mathrm{Ma}$, we show that at this time the Turkana Basin was hydrographically connected to the Indian Ocean, facilitating dispersal of fauna between these areas. From a biogeographical perspective, we propose that the Indian Ocean coastal strip should be considered as a possible source area for one or more of the multiple Homo species in the Turkana Basin from over 2 Ma onwards.

\section{Introduction}

The time interval around $2 \mathrm{Ma}$ is considered to be a key period in the hominin evolutionary history in Africa. It marks the first appearance of several taxa in the genus Homo (Wood, 2009; 
Wood and Leakey, 2011, Leakey et al., 2012), an increase in hominin brain size (e.g. Elton et al., 2001; Potts, 2011), and the earliest evidence for use of stone tools to butcher both terrestrial and aquatic fauna (Braun et al., 2010). Moreover, at that time at least three and possibly more hominin species co-existed in the Turkana Basin (Kenya, Ethiopia; Fig. 1; e.g. Wood and Leakey, 2011; Leakey et al., 2012; Wood, 2012). Many issues pertinent to hominin origins, radiation and dispersal in this time interval remain unresolved, including the phylogenetic relationships between different broadly contemporaneous hominin species in Africa (Spoor et al., 2007; Pickering et al., 2011), the ecological niches occupied by coexisting hominin species (Ungar and Sponheimer, 2011), and the possible influence of climatic and environmental change on hominin dispersal and evolutionary history (Behrensmeyer, 2006; deMenocal, 2011). In order to address these issues it is necessary to place hominin fossil occurrences from this crucial time interval in a high-resolution chronological framework providing temporal linkage to local and global paleoclimate records as well as to well-dated archeological records.

Recently, Joordens et al. (2011) developed a novel climate proxy specifically for Turkana Basin lacustrine deposits. The proxy method consists of combining strontium ( $\mathrm{Sr}$ ) isotope stratigraphy (measuring ${ }^{87} \mathrm{Sr} /{ }^{86} \mathrm{Sr}$ of fish apatite sampled from lake sediments) with highresolution magnetostratigraphy (providing the required age tie points) to resolve precessionforced wet-dry climate cycles. To obtain a high-resolution astronomically calibrated age and climate framework we employ age models based on ${ }^{40} \mathrm{Ar} /{ }^{39} \mathrm{Ar}$ ages of radiometrically-dated tuff layers (McDougall and Brown, 2006), as well as paleomagnetic reversal ages derived from astronomical calibration (Lourens et al., 2004; Gradstein et al., 2012). Hence, for internal consistency in this study we adjust available ${ }^{40} \mathrm{Ar} /{ }^{39} \mathrm{Ar}$ ages to an astronomical calibration (Kuiper et al, 2008). 
In the present study we apply this approach to date the fossil-rich hominin-bearing deposits of the $~ 2.0-1.87$ Ma upper Burgi Member on the Karari Ridge in the eastern Turkana Basin (Fig. 1). Since the early 1970 s important fossils attributed to early Homo have been and continue to be found in these particular deposits (Feibel et al, 1989; Wood, 1991; Wood and Leakey, 2011; Leakey et al., 2012). Examples include the crania KNM-ER 1470 (Leakey, 1973a) and KNMER 62000 (Leakey et al., 2012), the mandible KNM-ER 1802 (Leakey, 1974) and the femur KNM-ER 1481 (Leakey, 1973a). This approach allows us to significantly improve age control on these and 11 other important hominin fossils from this region, and to place them in a climatic and environmental context.

\section{Background}

\section{Setting}

The Turkana Basin is a hydrographic and sedimentary system encompassing about 131,000 $\mathrm{km}^{2}$ of northern Kenya and southern Ethiopia (Fig. 1; Feibel, 2011). Since $~ 4.2 \mathrm{Ma}$, the paleohydrology of the Turkana Basin is characterized by recurrent alternation of a major meandering river-floodplain system, and a lake system filling the basin. A persistent hydrological feature, the (paleo-)Omo River draining the vast Ethiopian Highlands supplied and supplies most ( $90 \%$ ) of the water in the basin (Feibel, 1999; 2011). Between $\sim 2.0-1.5$ Ma the Turkana Basin held the long-lived basin-wide Lake Lorenyang (Feibel, 2011), with a rich and diverse molluscan fauna demonstrating freshwater, non-alkaline conditions (Cerling, 1979; Vonhof et al., 2013). The presence of a hydrological connection between Lake Lorenyang and the Indian Ocean is documented by the first appearance of a marine-derived stingray in the basin at the onset of the Lorenyang lake phase. This fluvial system (named the "Turkana River") exited the basin in the SE and presumably followed the topography, 
controlled by the Central African Rift System, via the Anza Graben and Lamu Embayment to the Indian Ocean (Fig. 1; Feibel, 1993, 2011).

Our study focuses on the Karari ridge in the eastern part of the basin (Fig. 1) where the early part of the Lorenyang lake phase is recorded in deposits of the upper Burgi Member (UBU; Koobi Fora Formation), consisting of pelagic (deep lake), fluctuating lake margin, and deltaic sediments (Brown and Feibel, 1986, 1991; Feibel et al, 1991). The base of the lacustrinedeltaic UBU consists of a diachronous erosional unconformity surface, which due to local tectonic processes is expected to be of increasing age on a S-N axis from the Koobi Fora Ridge to the Karari Ridge and the Ileret and Il Dura regions (see Fig. 1; Feibel, 2011).

\section{Radiometric age control of early Lake Lorenyang deposits}

Early Lake Lorenyang deposits equivalent to the UBU are upper Member G ( submember G13 to Tuff H-2) of the Shungura Formation in the northern Turkana Basin, and the upper part of the Kalochoro Member (Nachukui Formation) in the western part of the Turkana Basin (Fig. 1; de Heinzelin, 1983; Lepre et al., 2011). Sedimentation in the northern and western Turkana Basin was continuous and hence in these regions the transition from fluviatile-floodplain to lacustrine conditions, the onset of Lake Lorenyang, is documented. In the eastern Turkana Basin, however, this was not the case and an estimated $\sim 400$ kyrs time interval below the base of the lacustrine-deltaic UBU is missing (Brown and Feibel, 1986). The Upper Burgi Member, Kalochoro Member, and Member G (plus submember H-1) are all capped by the KBS Tuff (see Table 1 for ages used in this study). Except for this well-established age of the top of the UBU, the age of UBU deposits on the Karari Ridge is at present poorly constrained. The deposits contain no additional tuff layers that could be radiometrically dated. Also, there are no regionally continuous marker beds that would allow correlation with the astronomically dated UBU deposits on the Koobi Fora Ridge (Joordens et al., 2011). 


\section{Paleomagnetic age control of early Lake Lorenyang deposits}

Previous paleomagnetic studies on early Lake Lorenyang sediments have been carried out in the northern Turkana Basin (Kidane et al., 2007), the western Turkana Basin (Lepre et al., 2011) and the eastern Turkana Basin (Brock and Isaac, 1974; Hillhouse et al, 1977; Braun et al., 2010; Joordens et al., 2011). In the northern Turkana Basin, Kidane et al. (2007) documented the presence of the base of the Olduvai chron (bC2n) dated at $1.945 \pm 0.004$ Ma (Horng et al., 2002; Lourens et al., 2004; Gradstein et al., 2012) and the presence of two normal polarity events below bC2n that were dated and interpreted by Kidane et al. (2007; Table 1) to belong to the Réunion subchron (Chamalaum and McDougall, 1966). The younger event was at about the same level as the onset of Lake Lorenyang deposits (Kidane et al, 2007; de Heinzelin, 1983). In the western Turkana Basin, Lepre et al. (2011) documented the base of the Olduvai Chron, plus a short normal polarity event $\sim 30 \mathrm{~m}$ below bC2n at $\sim 2 \mathrm{~m}$ above the onset of Lake Lorenyang deposits. These paleomagnetic data from the $\mathrm{N}$ and $\mathrm{W}$ Turkana Basin show that Lake Lorenyang started at or just before the occurrence of a short paleomagnetic normal event, likely -in view of its short duration- the younger "second Réunion" event, also named RU-2 excursion (e.g. Kidane et al., 1999; Quidelleur et al., 2010).

The age and especially the ubiquity of this RU-2 excursion are still debated (Kidane et al., 1999; Carlut et al., 1999; Lanphere et al., 2002; Kidane et al., 2007; Quidelleur et al., 2010; Ellis et al., 2012; Kindley et al., 2012). Globally distributed volcanic and sedimentary records show that the older Réunion event (RU-1) is associated with a large dipole intensity decrease and is recorded in many sequences (Quidelleur et al, 2010). The dipole intensity decrease was not as pronounced during RU-2 and consequently, RU-2 is not present as a full directional change in many sections worldwide, but rather appears in certain places as a geomagnetic excursion during an episode of increased secular variation (Quidelleur et al, 2010). Lanphere et al. (2002) proposed, based on correlation of RU-2 with 
the Huckleberry Ridge Tuff from Yellowstone (USA), that RU-2 be named the Huckleberry Ridge event. However, recent dating of the Huckleberry Ridge tuff complex by Ellis et al. (2012) has cast doubt on this association so we prefer to indicate this excursion by the name "second Réunion" or RU-2. A normal polarity excursion of similar age as RU-2 (in some cases accompanied by another one with a similar age as RU-1) has been detected in several regions in the eastern part of Africa: the Afar depression in Ethiopia (Kidane et al, 1999), the northern Turkana Basin in Ethiopia (Kidane et al, 2007) and western Turkana Basin (Lepre et al, 2011) in Kenya, and Sterkfontein in South Africa (Dirks et al, 2010; Herries and Shaw, 2011). Kindley et al. (2012) confirmed previous work by Kidane et al. (1999) that RU-2 was recorded in Gammari in Ethiopia (Table 1). This indicates that in eastern Africa there is evidence for the occurrence of a double Réunion subchron. We therefore conclude that the RU-2 can be used as a local time anchor marking the onset time of Lake Lorenyang in the Turkana Basin. We assume that at present $2.08 \pm 0.04 \mathrm{Ma}$ is the best approximation for the age of RU-2 (representing the minimum age of the onset of Lake Lorenyang) and hence for the maximum age of the UBU sections in Areas 131 and 105.

In the eastern Turkana Basin (Area 41; Fig. 1) Braun et al. (2010) documented the base of the Olduvai chron at $\sim 14 \mathrm{~m}$ below the KBS Tuff, plus a short normal polarity excursion at $\sim 5 \mathrm{~m}$ below the base of the Olduvai chron. Joordens et al. (2011) found in Area 102 (Fig. 1) the base of the Olduvai chron at $\sim 80 \mathrm{~m}$ below the KBS Tuff. At the Karari Ridge, our study area, the available paleomagnetic data are equivocal. The results of Brock and Isaac (1974) in Area 105 on the Karari Ridge (Fig. 1) suggest the presence of the base of the Olduvai chron $\sim 20$ m below the KBS Tuff, based on exclusively normal directions above that level and a mix of reversed and normal polarity directions below. In Area 131 on the Karari Ridge (Fig. 1), early work of Hillhouse et al. (1977) suggests that normal palaeomagnetic polarity extends to $\sim 14$ to $15 \mathrm{~m}$ below the KBS Tuff, followed by one sample with reversed polarity, then normal polarity again between 17 and $20 \mathrm{~m}$ below KBS Tuff, followed by 
reversed polarity to $\sim 35 \mathrm{~m}$ below KBS. In the lowermost $5 \mathrm{~m}$ of the UBU section they find normal polarity again (Hillhouse et al., 1977). McDougall et al. (2012) mention that the polarity transition at $\sim 15 \mathrm{~m}$ below the KBS Tuff in Area 131 almost certainly represents the bottom of the Olduvai chron, whereas the piece of section with normal polarity lower in the sequence may either be spurious (normal polarity overprint) or represents a geomagnetic excursion. The relatively low sample resolution in these studies from the 1970's, and the possible occurrence of normal overprint, precludes the precise definition of polarity reversal positions necessary for reliable magnetostratigraphic age constraints. This lack of reliable paleomagnetic results in the lower part of the UBU sections on the Karari Ridge has motivated the high-resolution magnetostratigraphic analysis presented here.

\section{Magnetostratigraphy}

\section{Methods}

Paleomagnetic sampling was performed in 2010 in sediments of the upper Burgi Member in Area 105 and Area 131 on the Karari Ridge in the eastern Turkana Basin (Fig. 1). We obtained a complete stratigraphic succession undisturbed by faults, by stacking several carefully correlated nearby subsections (Fig. 2, Tables A.1 and A.2 in the Appendix). This was done by physically tracing distinctive correlative beds from one subsection to the next. Subsections were measured and trenched, and the lithology was described, after which paleomagnetic samples were taken at $\sim 50 \mathrm{~cm}$ intervals. Paleomagnetic samples consisted of standard $2.5-\mathrm{cm}-$ diameter cylindrical rock cores drilled with an electric drill mounted with a diamond-coated bit and cooled with an electric air compressor, both devices powered by a portable generator. Loose sandy intervals were sampled by pressing $2.5 \mathrm{~cm}$ diameter quartz glass cylinders, filled with a sodium silicate solution for in situ hardening, into the sediment. Samples (cores and cups) were oriented with a compass and clinometer and no dip corrections were necessary for these flat lying sediments. Orientations were corrected for the local $1.5^{\circ}$ declination. 
Paleomagnetic processing was performed using 2G DC squid magnetometers at the paleomagnetic laboratories of the Rennes 1 University (France) and the CENIEH in Burgos (Spain). There were no significant differences in the results from these laboratories. Demagnetization procedures followed methods described in Dupont-Nivet et al. (2008) and Joordens et al. (2011). Detailed analysis of pilot samples for both studied areas revealed the same type of demagnetization behaviors, very similar to those obtained from Area 102 presented in Joordens et al. (2011). Alternating Field (AF) demagnetization of pilot samples was often biased by gyroremanence at higher applied fields while thermal demagnetization gave superior Characteristic Remanence Magnetization (ChRM) component separation and was used in all following processing (Fig. 3). Of all 153 demagnetized samples, only four with erratic paths and weak magnetization yielded no interpretable paleomagnetic directions. For most other demagnetized samples (91 out of 149; Table 2, 3), after removal of a common normal overprint up to $200-300{ }^{\circ} \mathrm{C}$, the ChRM was determined by a steady decay towards the origin up to $400-550{ }^{\circ} \mathrm{C}$ (Fig. 3) typical of Ti-rich titanomagnetites carrying the remanence similarly to results from area 102 (Joordens et al., 2011). ChRM directions were then calculated using least square analysis (Kirschvink, 1980) on a minimum of four consecutive steps of the ChRM. These line fits provide reliable paleomagnetic direction estimates (labeled "quality 1") and were obtained without forcing to the origin (Table 2, 3). For most other samples (38), obtained directions provide reliable polarity estimates (labeled "quality 2") but directions were obtained using other methods for the following reasons: (1) Noisy demagnetization paths required forcing line fits through the origin or (2) a normal overprint partially overlapping with the reversed ChRM was clearly indicated by demagnetization paths along a great circle on stereographic projections (Fig. 3c). In the latter cases, best fit great circle analyses were performed using the mean of previously obtained "quality 1" reversed directions as set points (McFadden and McElhinny, 1988). Finally, 10 samples were qualified 
unreliable in direction and polarity ("quality $3 ")$ because they yielded widely aberrant directions or isolated levels of opposite polarity. These directions are interpreted either as transitional during reversals and excursions, or as delayed acquisition in sediments below a reversal. The obtained ChRM directions have maximum angular deviation (MAD) below $30^{\circ}$ (average is $12^{\circ}$ ). Excluding quality 3 directions, they cluster around antipodal normal- and reverse-polarity mean directions (Fig. 3d, 3i) and pass the reversals test (McFadden and McElhinny, 1990) with class C. This suggests stability of the ChRMs, successful exclusion of normal overprint bias and a reliable magnetic polarity zonation for the sections in both Area 105 (KS sections) and Area 131 (KR sections).

\section{Results}

Base of the Olduvai chron in Area 105 and 131 - The transition of reversed polarity directions in the lower part of the UBU, to normal polarity in the upper part of the UBU, unequivocally and precisely locates the base of the Olduvai chron in the sampled sections (Table 2, 3; Fig. 4). In the UBU section of Area 105, the reversal to $\mathrm{bC} 2 \mathrm{n}$ is precisely indicated between 21.3 to $21.9 \mathrm{~m}$ below the KBS Tuff (Fig. 4a, f, g). Three isolated directions of seemingly normal polarity, positioned just below and up to $2.0 \mathrm{~m}$ below the reversal, may be interpreted as resulting from delayed acquisition of a normal overprint (van Hoof and Langereis, 1991). In the UBU section of Area 131, the base of the Olduvai chron is situated between the 30.2 and $32.0 \mathrm{~m}$ levels (14.0 to15.8 m below the KBS Tuff; Fig. 4a, b, c). In between, two samples taken in sands at the $31.5 \mathrm{~m}$ level yield mixed results of transitional and normal directions respectively, suggesting recording of the polarity reversal (Table 2). These results confirm the results of earlier studies that located the bottom of the Olduvai chron in Area 105 at $\sim 20 \mathrm{~m}$ below KBS Tuff (Brock and Isaac, 1974) and in Area 131 at 15 m below KBS Tuff (Hillhouse et al., 1977). 
Pre-Olduvai event in Area 131 - In Area 131, a short isolated interval of consistently normal polarity directions is situated within the 23.7 to 24.6 meter level, at 21.4 to $22.3 \mathrm{~m}$ below KBS Tuff (Table 3, Fig. 4a, b, c). This may result from normal overprinting coinciding with soil formation; however, such overprinting has not been found in any of the other soil layers in these sequences. Delayed acquisition is also unlikely given the large stratigraphic interval $(\sim 7$ meters) below the normal polarity zone $\mathrm{bC} 2 \mathrm{n}$. The conspicuous position of this interval suggests it represents one of the geomagnetic excursions reported below bC2n. Because of its stratigraphic position near the base of the Olduvai chron (and with another 23.5 meters of lacustrine sediments beneath), it is more reasonable to relate this interval to the so-called "preOlduvai" event dated at 1.977 $\pm 0.002 \mathrm{Ma}$ (Channell and Guyodo, 2004; Laj and Channell, 2007; Roberts, 2008; Pickering et al., 2011) than to the much older normal polarity RU-2 event $(\sim 2.08 \pm 0.04 \mathrm{Ma}$; Table 1$)$ documented at or just above the onset of Lake Lorenyang deposits in the $\mathrm{N}$ and W Turkana Basin (Kidane et al., 2007; Lepre et al. 2011). Our tentative identification of the Pre-Olduvai event in Area 131 should be confirmed by documenting it in other laterally correlated records. As mentioned previously, indications for the possible presence of this geomagnetic polarity have been found in the eastern Turkana Basin (Braun et al, 2010) and in Sterkfontein, South Africa (Pickering et al, 2011).

Absence of other geomagnetic events in Area 131 - From the base of the UBU section up to $35 \mathrm{~m}$ below the KBS Tuff (m level 11) in Area 131 we found exclusively reversed polarities (Table 3, Fig. 4b, c). This indicates that the normal polarities previously measured in this interval by Hillhouse et al. (1977) are, as suggested by McDougall et al. (2012), spurious and do not represent a geomagnetic excursion. This is likely due to their use of Alternating Field demagnetization and the low sensitivity spinner magnetometer failing to separate and identify 
normal overprinting of a primary reversed magnetization. We therefore conclude that no other geomagnetic event has been recorded in this time interval of area 131.

\section{Strontium isotope stratigraphy}

As shown in Joordens et al. (2011), the unique, relatively simple hydrological situation of the Turkana Basin offers the rare opportunity to capture -with Sr isotopes- the monsoonal rainfall signal in a continental setting: the (paleo-)Omo River draining the Ethiopian Highlands was and is the main water source $(\sim 90 \%)$ feeding the Turkana Basin, with small rivers from the Southwest being minor water sources ( $10 \%$; Yuretich, 1979; Feibel et al., 1991). Since the catchment geology of the Omo and SW drainage areas differs, the rivers have different chemical compositions and variation of relative river contribution to the lake causes changes in lake water chemistry (Yuretich, 1979). The (paleo-)Omo River catchment drains mainly Tertiary flood basalts with relatively low ${ }^{87} \mathrm{Sr} /{ }^{86} \mathrm{Sr}$ values $(\sim 0.704)$, whereas river catchments in the SW drain metamorphic Precambrian basement terrains with relatively high ${ }^{87} \mathrm{Sr} /{ }^{86} \mathrm{Sr}$ values $(\sim 0.720$; Talbot et al., 2000). Thus, during wet periods of strong monsoonal rainfall in the Ethiopian Highlands, the proportion of Omo water in the lake is expected to be relatively high, and ${ }^{87} \mathrm{Sr} /{ }^{86} \mathrm{Sr}$ values of lake water would tend towards that of Ethiopian Flood basalts $(\sim 0.704)$. During dry periods in Ethiopia, the proportion of Omo water in the lake would be somewhat lower and ${ }^{87} \mathrm{Sr} /{ }^{86} \mathrm{Sr}$ values of lake water would increase.

Lacustrine $\mathrm{Sr}$ isotope $\left({ }^{87} \mathrm{Sr} /{ }^{86} \mathrm{Sr}\right)$ variation is solely driven by water provenance, so variation in lake water ${ }^{87} \mathrm{Sr} /{ }^{86} \mathrm{Sr}$ over time can be used as a proxy for variation in rainfall intensity over the Ethiopian Highlands. This variation is faithfully recorded in organisms living in the water: ${ }^{87} \mathrm{Sr} /{ }^{86} \mathrm{Sr}$ values of well-preserved aquatic fossils (e.g. fish bones and teeth) from lake sediments directly reflect ${ }^{87} \mathrm{Sr} /{ }^{86} \mathrm{Sr}$ values of the host water, and are not affected by temperature 
variation or ecological parameters (Talbot, 2000; Vonhof et al., 2003). Due to the hydrologically conservative behavior of $\mathrm{Sr}$ in a lake system, $\mathrm{Sr}$ is sensitive to changes on orbital timescales but insensitive to changes on submillenial timescales: spectral analysis has shown that $\mathrm{Sr}$ isotope ratios reflect changes in monsoonal rainfall on precession $(\sim 20 \mathrm{kyr})$ timescales (Joordens et al., 2011).

\section{Methods}

Samples of unweathered sediment were taken at $1 \mathrm{~m}$ intervals in the same UBU subsections in Areas 105 and 131 where paleomagnetic samples were taken. Sediment samples (ca. 5 $\mathrm{cm}^{3}$ each) were wet-sieved over a $600-\mu \mathrm{m}$ sieve and, when present, optically well-preserved fish fossils (bones, teeth) were picked under a binocular microscope. Excellent preservation of fish fossils was confirmed by SEM inspection. Only minor diagenetic $\mathrm{CaCO}_{3}$ overgrowths were encountered in cracks or voids in some of the fish fossils. To effectively remove such possibly contaminant $\mathrm{CaCO}_{3}$, fish fossil fragments were leached for $\sim 1 \mathrm{~h}$ in $5 \mathrm{~N}$ acetic acid prior to Sr separation. The remaining fish apatite was dissolved in $3 \mathrm{~N} \mathrm{HNO}_{3}$, after which $\mathrm{Sr}$ was separated using Elchrom Sr spec ion exchange resin. ${ }^{87} \mathrm{Sr} /{ }^{86} \mathrm{Sr}$ ratios were analyzed on a Finnigan MAT 262 mass spectrometer at the department of Earth Sciences of the VU University Amsterdam, running a triple jump routine and applying exponential fractionation correction. All ${ }^{87} \mathrm{Sr} /{ }^{86} \mathrm{Sr}$ data are reported relative to a value of 0.710243 for the routinely analyzed NBS 987 standard. Sr in blanks was $<0.1 \%$ of the total Sr in the samples.

\section{Results}

From the 31 sediment samples taken in Area 105, only six yielded fish apatite suitable for $\mathrm{Sr}$ isotope analysis. In Area 131, 46 sediment samples were taken and 11 yielded sufficient and suitable apatite. This can be explained by the fact that in the largely deltaic UBU deposits on 
the Karari Ridge, with large variations in depositional environments, fish apatite is not as consistently abundant and well preserved throughout the successions as in more pelagic sediments such as the UBU in Area 102 (Joordens et al., 2011). To complement the datasets, we included six Sr isotope values measured on fish apatite previously sampled by one of us (CSF) from well-constrained stratigraphic levels in the same sections in Areas 105 and 131 (Table 4, 5). Although the Sr isotope records from these Karari sequences are short, they are valuable because they contain climate information and give a measure of time: as shown by Joordens et al. (2011), a strontium isotope cycle recorded in lacustrine Turkana basin deposits reflects a precession cycle of $\sim 17-23 \mathrm{kyr}$ duration. Moreover, the $\mathrm{Sr}$ isotope records can be directly correlated to both paleomagnetic reversals and hominin fossil occurrences.

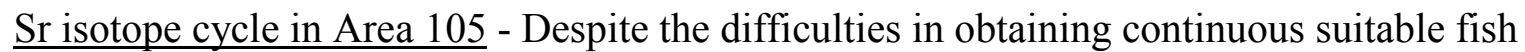
apatite records, we were able to capture a single well-resolved $\mathrm{Sr}$ isotope precessional cycle in ca. 6 to $7 \mathrm{~m}$ of section in the lower part of the UBU sequence in Area 105 (Table 4, Fig. 4h). The ${ }^{87} \mathrm{Sr} /{ }^{86} \mathrm{Sr}$ values of the cycle in Area 105 range between 0.7054 and 0.7048 : on average 0.7051, with amplitude ca. 0.0006 . The Sr isotope cycle spans the base of the Olduvai chron (Fig. 4g, h), and thus can be compared to the Sr isotope cycle of the same age recorded in the UBU of Area 102 (Joordens et al., 2011). In both Areas 105 and 102, it was found that bC2n is situated close to a peak dry in the Sr isotope cycle (in the phase going from dry to wet conditions) confirming the hypothesis that the observed cycles in these records are contemporaneous. The climate phase relationship appears to contradict that of the astronomically calibrated age of bC2n (1.945 \pm 0.004 Ma; Horng et al., 2002) which corresponds to a precession minimum and insolation maximum (Laskar et al., 2004) and hence to peak wet conditions (Tuenter et al., 2003). However, we point out that the error in this age of $\mathrm{bC} 2 \mathrm{n}$ does not include the additional uncertainties (likely less than a precession cycle) that 
arise from the astronomical tuning process (Horng et al., 2002), and thus at present this age of $\mathrm{bC} 2 \mathrm{n}$ cannot be used to resolve a climate phase relationship.

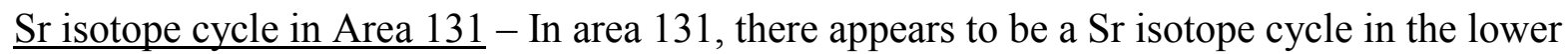
part of the section, although this cycle is not as well-resolved as the cycle in Area 105 and may record (part of) a second cycle as well (Table 5, Fig. 4d). The ${ }^{87} \mathrm{Sr} /{ }^{86} \mathrm{Sr}$ values of the cycle range between 0.7049 and 0.7047 : on average 0.7048 with amplitude ca. 0.0002 . Four additional $\mathrm{Sr}$ isotope values were obtained from fish apatite found at levels higher in the sequence of Area 131 (from above the $20 \mathrm{~m}$ level), but the number and resolution of these data points was too low to resolve more cycles. The Sr isotope values of these four samples are higher (0.7050) than those low in the section (Table 5). This suggests that the Sr isotope values in Area 131 increase over time, similar to the trend observed in the Sr isotope record of the UBU Area 102 where the values increase from ca. 0.7049 low in the section (below bC2n) to ca. 0.7055 higher in the section just below the KBS Tuff. As proposed for Area 102 (Joordens et al., 2011), the trend could be explained either by slowly changing water chemistry (e.g. due to a gradual change in river course, delta progradation) in the catchments feeding the Turkana Basin, or by a gradual relative decrease in monsoon rainfall in the Omo River catchment.

Comparison of the $\mathrm{Sr}$ isotope values from Areas 105 and 131 - The average value of the $\mathrm{Sr}$ isotope cycle in Area $131(0.7048)$ is low compared to that of the cycle in Area 105 (0.7051). This is, in view of the apparent general trend in the Sr isotope record of the UBU, in agreement with the magnetostratigraphic results indicating that the cycle in Area 131 is significantly older than that of Area 105 (Fig. 4). In addition, the amplitude of the cycle in Area 131 (0.0002) appears to be considerably smaller than the amplitude of the cycle in Area 105 (0.0006), which 
suggests that the difference in monsoonal intensity between wet and dry phases of the precession cycle was smaller in this time period than around the base of the Olduvai chron.

\section{Age model calculations}

\section{Methods}

Our magnetostratigraphic results provide, to complement the radiometrically-dated KBS Tuff (1.876 \pm 0.021 ; Table 1), a well-dated temporal anchor to be employed in the calculation of age models for the UBU deposits on the Karari Ridge: the base of the Olduvai chron (bC2n, $1.945 \pm 0.004 \mathrm{Ma})$. The age of the younger Réunion event (RU-2; $2.08 \pm 0.04 \mathrm{Ma}$ ) represents the minimum age of the onset of Lake Lorenyang, and hence the maximum age of the UBU sections in Areas 131 and 105.

\section{Results}

$\underline{\text { Age model Area } 105}$ - Applying the available astronomically calibrated age tie points implies that in Area 105 the mean sediment accumulation rate between bC2n and the KBS Tuff is 31.3 $\pm 9 \mathrm{~cm} / \mathrm{kyr}$ (Table 6). This value agrees well with the sediment accumulation rate of $31 \mathrm{~cm} / \mathrm{kyr}$ that can be derived from the Sr isotope cycle in Area 105 (Fig. 4h) with $\sim 6.5 \mathrm{~m}$ of sediments representing one precession cycle of $21 \mathrm{kyr}$. Linear extrapolation of the rate $31.3 \pm 9 \mathrm{~cm} / \mathrm{kyr}$ downwards from the KBS Tuff places the base of the section in Area 105 at $1.986 \pm 0.052 \mathrm{Ma}$, taking into account the error of the age of the KBS Tuff and that of the sediment accumulation rate. The same extrapolation applied downwards from bC2n yields an age of $1.979 \pm 0.014 \mathrm{Ma}$ for the base of the section. This is in line with the documented absence of normal polarities below bC2n (Fig. 4f, g), indicating that the base of the UBU section in this area is slightly younger than the Pre-Olduvai event at $1.977 \pm 0.002 \mathrm{Ma}$. It also suggests that the Pre-Olduvai event may be located just below the measured section in Area 105, and that future 
magnetostratigraphic analysis may find it there by extending the sampled section downward a few meters (Table 6).

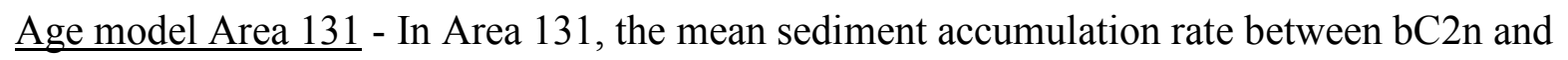
the KBS Tuff is $21.6 \pm 7 \mathrm{~cm} / \mathrm{kyr}$ (Table 6). Linear extrapolation of this rate downwards from $\mathrm{bC} 2 \mathrm{n}$ to the stratigraphic level of the short normal polarity excursion below bC2n (m level 24; Fig. 4) yields an age $1.981 \pm 0.016 \mathrm{Ma}$ for this level, which supports our interpretation that this polarity excursion is the Pre-Olduvai event dated to $1.977 \pm 0.002 \mathrm{Ma}$. Linear extrapolation of the rate of $21.6 \pm 7 \mathrm{~cm} / \mathrm{kyr}$ downwards from from the KBS Tuff to the base of the section yields an age of $2.114 \pm 0.098 \mathrm{Ma}$ for the base of the section, taking into account the error of the age of the KBS Tuff and the error of the sediment accumulation rate. The same extrapolation applied downwards from bC2n yields an age of $2.106 \pm 0.056 \mathrm{Ma}$ for the base of the section, These calculated ages are greater than the maximum age defined for the base of section in Area $131(2.08 \pm 0.04 \mathrm{Ma}$; Table 1) suggesting that accumulation rates in the lower part of the section were slightly higher, at least $23.0 \pm 9 \mathrm{~cm} / \mathrm{kyr}$.

\section{Age of the sediments and fossils}

Age of marker beds

Our results show that intraformational conglomerate layers GPC (also named marker bed g) and LCC (marker bed h), previously assumed to be reliable marker beds for correlation between areas (Feibel et al, 1989), are not synchronous in Areas 105 and 131: the conglomerate bed identified as "GPC" in Area 105 is time-equivalent to conglomerate bed LCC in Area 131 (Fig. 4e, i). This demonstrates that these similar looking conglomerate beds, while useful as marker beds for local correlations (if the beds can be continuously traced between the sections), are not suitable for making regional stratigraphical correlations. For 
instance in Areas 130 and 115, a conglomerate bed "GPC" has been used as a stratigraphic marker for hominin fossils occurrences (Feibel et al., 1989; Leakey et al., 2012) but our data suggest it cannot be assumed that these conglomerate beds are synchronous with the GPC bed in Area 131, or Area 105. Hence care should be taken in making inferences on correlation and ages of these fossils from different areas, based solely upon sedimentological comparisons.

\section{Age control on hominin fossils}

The lithology of the sampled section of Area 131 is now logged in such detail that we can correlate it with a published detailed log section providing the stratigraphic positions of hominin fossils that have been found in the UBU of this area (Leakey, 1973a,b; Leakey, 1974; Leakey et al., 2012). Figure 5 shows the lithostratigraphic correlation between the Area 131 $\log$ from this study (Fig. 5a) and the Area $131 \log$ from Leakey (1973a; Fig. 5b). The correlation allows placement of KNM-ER 1481 in the sandy interval below GPC, between the 30.6 and $31.0 \mathrm{~m}$ level of our stratigraphy (Fig. 5a, see also Fig. 4e). KNM-ER 1470 can be precisely placed at the $5 \mathrm{~m}$ level in our stratigraphy (Fig. 5a, Fig. 4e) because our sampling section includes the site of KNM-ER 1470, and can also be correlated to the Leakey log (Fig. 5b). The other hominin fossils from the Leakey log (KNM-ER 1472, 1473, 1475) are constrained by the GPC (m level 24.6) and the stratigraphic position of KNM-ER 1470 (m level 6; Fig. 5b). KNM-ER 62000 was recently discovered in Area 131 and derives from just above the GPC bed (Leakey et al., 2012) so it can be assigned to meter level 25 in our stratigraphy (Fig. 4e). The mandible KNM-ER 1802 (Leakey, 1974) derives from below level GPC ("GPC-“; Feibel, 1989), and while it is not exactly known how far below, it is unambiguously older than KNM-ER 62000. Mandible KNM-ER 1482 (Leakey, 1973b) derives from a stratigraphic level between that of KNM-ER 1475 and KNM-ER 1472 (Feibel, 1989; Fig. 5b). Mandible KNM-ER 1801 (Leakey, 1974) was found at a level below a marker bed 
called F, which according to Feibel (1989) is situated $\sim 30 \mathrm{~m}$ below KBS Tuff, so it is stratigraphically close to KNM-ER 1472 (Fig. 5b).

It is now possible to provide improved age constraints for all 15 hominin fossils that were found in Area 131 (Leakey et al., 1973a, b; Leakey, 1974; Feibel et al., 1989; Leakey et al., 2012; Table 7). The age of five of the hominin fossils can be more precisely controlled. KNMER 1481, KNM-ER 1803 and KNM-ER 1469 derive from just below the base of the Olduvai chron and $\sim 7 \mathrm{~m}$ above the Pre-Olduvai event and thus are constrained between $1.945 \pm 0.004$ and $1.977 \pm 0.002$ Ma. KNM-ER 62000 derives from just above the Pre-Olduvai event and is similarly constrained between $1.945 \pm 0.004$ and $1.977 \pm 0.002 \mathrm{Ma}$. We have established that KNM-ER 1470 derives from $26 \mathrm{~m}$ below bC2n, $19 \mathrm{~m}$ below the base of the Pre-Olduvai event, and $5 \mathrm{~m}$ above the base of the section (reported here). We can provide an age estimate for this important fossil by calculating an age based on meters below bC2n, using a calculated average accumulation rate below bC2n in Area 131. The average accumulation rate, based on a maximum age of $2.08 \pm 0.04 \mathrm{Ma}$ for the base of the section, is $23.0 \pm 9 \mathrm{~cm} / \mathrm{kyr}$ (Table 6). Our calculation results in an age of $2.058 \pm 0.034 \mathrm{Ma}$ for KNM-ER 1470 (Table 6). This is somewhat older than a previous age estimate for KNM-ER 1470 (2.03 \pm 0.05 Ma; McDougall et al., 2012) and calculated at higher precision.

\section{Discussion and conclusions}

Implications of improved age control for early Homo

Several of the hominin fossils for which improved age estimates are reported here are key specimens in a recent study that reconsiders early Homo in eastern Africa on the basis of new fossil evidence from Koobi Fora (Leakey et al., 2012). One of the new fossils described in that study is a partial face, KNM-ER 62000, which shows strong similarities to KNM-ER 1470. Its 
well-preserved palate and teeth make it possible to infer aspects of the mandible that occluded with the distinctive upper dental arcades of KNM-ER 1470 and KNM-ER 62000. Good matches are not only KNM-ER 60000, a new, nearly complete early Homo mandible from above the KBS Tuff in Area 105, but also the partial mandibles KNM-ER 1482 and KNM-ER 1801 from UBU deposits considered here. In contrast, the mandible KNM-ER 1802, which has been most commonly associated with KNM-ER 1470, is shown to be an unlikely match (Leakey et al. 2012). As such Leakey et al. (2012) find both cranial and mandibular evidence for two species of early Homo. These are often referred to as H. rudolfensis for KNM-ER 1470 and associated specimens, and $H$. habilis for other, subnasally more prognathic specimens (Wood 1992, 2012), but Leakey et al. (2012) refrain from assigning species names because they feel that the association of the H. habilis type specimen $\mathrm{OH} 7$ is not yet fully resolved. Our current study provides older ages for KNM-ER 1470, KNM-ER 1482, KNM-ER 1801 and KNM-ER 62000 than previously estimated (Feibel et al., 1989; Leakey et al., 2012). These data appear to support an interpretation of the early Homo fossil record that specimens assigned to $H$. rudolfensis predate those assigned to $H$. habilis, i.e., these species form timesuccessive segments of a single anagenetic evolutionary lineage rather than separate, contemporary species (Suwa et al., 1996). However, our findings equally increase the age of KNM-ER 1802, a specimen unlikely to be associated with KNM-ER 1470 and KNM-ER 62000. Moreover, early occurrence of a more subnasally prognathic morphology is shown by Homo specimens OH 24 (1.9 Ma; Hay, 1976; Walter et al., 1991) and A.L. 666-1 (2.33 Ma; Kimbel et al., 1996), whereas the occurrence of the 'KNM-ER 1470 group' in younger, postUBU times is indicated by KNM-ER 60000 dated to $1.78-1.87 \mathrm{Ma}$ (Leakey et al., 2012). Hence, the dates now available are consistent with a temporal overlap of two species of early Homo that can be distinguished by their facial morphology (sensu Leakey et al., 2012). 
The revised, older dates obtained here for early Homo specimens do not support the suggestion that Australopithecus sediba preserved at Malapa, South Africa, could have been ancestral to Homo because at $1.977 \pm 0.002 \mathrm{Ma}$ it would be older than the oldest uncontested representatives of this genus (Pickering et al., 2011). Regardless of other arguments, such as the premature dismissal of the Homo affinities of the A.L. 666-1 maxilla from Hadar (Spoor, 2011), it is now clear that several early Homo fossils reassessed here are chronologically constrained between $1.977 \pm 0.002$ and the base of section at $2.08 \pm 0.04 \mathrm{Ma}$, and thus older than any known A. sediba specimens. Most prominent among these fossils is KNM-ER 1470, now dated to $2.058 \pm 0.034 \mathrm{Ma}$.

The femur KNM-ER 1481 derives from just (at maximum $\sim 30 \mathrm{~cm}$; Fig. 4, 5) under the base of the Olduvai chron, resulting in an age of slightly older than $1.945 \pm 0.004$ (Fig. 4e). Wood and Leakey (2011) attribute this fossil to Homo erectus. If confirmed, this would make KNM-ER 1481 the oldest securely dated H. erectus fossil found so far, just older than the innominate KNM-ER 3228, also attributed to this species by Wood and Leakey (2011) and assigned an astronomically tuned age of $1.92 \mathrm{Ma}$ (Joordens et al., 2011). Nevertheless, at present it cannot be excluded that the femur and innominate belong to $H$. rudolfensis instead of $H$. erectus. The prime importance of the dating evidence is that it confirms the presence of a hominin with modern human-like locomotion (Richmond and Jungers, 2008; Harmon, 2009) in the Turkana Basin as early as $\sim 1.95 \mathrm{Ma}$.

\section{Implications of orbitally forced climate cycles for hominin presence}

Joordens et al. (2011) concluded that in the time interval between $\sim 1.87$ and $1.99 \mathrm{Ma}$ hominins from the Koobi Fora Ridge and Bura Hasuma in the eastern Turkana Basin were present throughout dry and wet phases of precession cycles. Moreover, this study suggested that the lacustrine Turkana Basin was an oasis-like refugium for water-dependent fauna during 
regionally dry periods. This hypothesis can now be tested with the well-dated hominin fossils from the Karari Ridge. Our Sr isotope and magnetostratigraphic results indicate that KNM-ER 1481 and KNM-ER 1803, deriving from just below bC2n, can be correlated with a dry phase of the precession cycle (Table 7, Fig. 4, 5). KNM-ER 1470 occurred in a relatively wet phase of the precession cycle (Fig. 4d, e). Based on stratigraphic levels of KNM-ER 1474, KNM-ER 1801, KNM-ER 1472 and KNM-ER 1471 (deriving from levels 4, 5, 6 and 9 m respectively above KNM-ER 1470; Table 7) we can infer that they are correlated with different phases of that same precession cycle (Fig. 4). Thus, our results suggest that also in the time interval between $2.058 \pm 0.034$ and $1.945 \pm 0.004 \mathrm{Ma}$, hominins occurred throughout the wet-dry cycles, providing further supporting evidence for the proposed hypothesis that the lacustrine Turkana Basin was an aridity refugium during regionally dry periods (Joordens et al, 2011).

However, it should be taken into account that precession cycles are modulated by the $100 \mathrm{kyr}$ and 400 kyr Earth eccentricity cycles: the more oblate the Earth's orbit (higher eccentricity value), the larger is the amplitude of the precession and insolation cycles (Fig. 6; Laskar et al., 2004). Given the importance of precession forcing to the monsoon, eccentricity is expected to influence the intensity of monsoonal fluctuations (e.g. Wang et al, 2010). Hence during an eccentricity minimum, the variation in monsoonal intensity and thus of Omo River water input over a precession cycle would be minimal, and as a result the amplitude in Sr isotope cycles would be small. During the early UBU time interval and especially in the period between 2.08 and $1.98 \mathrm{Ma}$, eccentricity values were very low, with a minimum of $\sim 0.005$ occurring at 2.06 Ma (Laskar, 2004; Fig. 6). As a consequence, the amplitude of monsoonal wet-dry fluctuations, and hence of fluctuations in Omo River input into the Turkana Basin, can be expected to have been minimal then. At 1.94-1.95 Ma, the eccentricity value was relatively high $(\sim 0.037$; Fig. 6$)$ and the amplitude of the fluctuations in Omo river water input would 
have been relatively large then. Indeed, occurrence of this phenomenon appears to be reflected by the small amplitude (0.0002) of the Sr isotope cycle in Area 131 around $2.06 \mathrm{Ma}$, compared to the larger amplitude (0.0006) of the younger cycle around 1.95 Ma in Area 105 (Fig. 4, 6).

In the time interval just above the KBS Tuff, from $\sim 1.87$ to $1.82 \mathrm{Ma}$, the eccentricity was maximal (Fig. 6), which would have caused more extreme fluctuations in precessional (monsoonal intensity) amplitude, and hence in Omo River input into the lake. This is corroborated by the observed major lake level fluctuations in the KBS Member overlying the UBU (Lepre et al, 2007). It is therefore recommended to test the aridity refuge hypothesis also in deposits above the KBS Tuff in order to study if/how the high eccentricity value affected hominin presence in the fluctuating lakeshore deposits. The improved age control presented in this study can also be applied to non-hominin fossil faunal occurrences in the upper Burgi Member, allowing future analysis of the sensitivity of faunal communities to eccentricitymodulated precessional patterns of climatic and environmental change.

Finally, we wish to draw attention to the implications of our results in a wider biogeographical context. By providing an age estimate for the level at which KNM-ER 1470 was found, we also establish the (observed) first appearance datum of the stingray Dasyatis africana in the Turkana Basin at $2.058 \pm 0.034 \mathrm{Ma}$ (Fig. 4e), instead of at $\sim 1.9$ Ma as previously estimated (Feibel, 1993). The sudden appearance of marine-derived stingrays in the fossil record (combined with the absence of stingray fossils from older levels) indicates that the appearance signifies the establishment of a hydrographic connection, and hence a possible dispersal route for water-dependent fauna, between the Indian Ocean and the Turkana Basin. Leakey et al. (2008) concluded that many species of fossil cercopithecid monkeys that first appeared in the Turkana Basin without obvious local predecessors are likely to have dispersed to the basin 
while having evolved elsewhere. The authors inferred that waterways with gallery forests linking the Turkana Basin with habitats elsewhere would have been critical in facilitating this dispersal, and recognized that Central African forests and particularly the eastern African coastal forest along the Indian Ocean would have provided ideal habitats for primate evolution (as proposed by Kingdon, 2003). This could have also been the case for hominins (Joordens et al, 2012), and we therefore propose that the Indian Ocean coastal strip should be considered as a possible evolutionary source area for one or more of the multiple Homo species that appeared in the Turkana Basin from over 2 Ma onwards.

\section{Acknowledgements}

We gratefully acknowledge the Government of Kenya and the National Museums of Kenya and for facilitating our research in the Koobi Fora region. This study was supported by: the Netherlands Organisation for Scientific Research (NWO), the Leakey Foundation, the Center for Human Evolutionary Studies (CHES, Rutgers University), and The National Science Foundation (NSF USA). We thank the Turkana Basin Institute, the Koobi Fora Research Project (notably Louise Leakey and Meave Leakey) and Henning Scholz for logistical support and collaboration in the field. Martijn Klaver provided analytical assistance at the VU University Amsterdam. We thank Wil Roebroeks and María Martinón-Torres for commenting on an earlier version of this paper, and we are grateful to two anonymous reviewers whose comments greatly improved this paper.

\section{References}

Behrensmeyer, A.K., 2006. Climate change and human evolution. Science 311: 476-478. Berger, L.R., de Ruiter, D.J., Churchill, S.E., Schmid, P., Carlson, K.J., Dirks, P.H.G.M., Kibii, J.M., 2010. Australopithecus sediba: a new species of Homo-like Australopith from South Africa. Science 328: 195-204

Braun, D.R., Harris, J.W.K., Levin, N.E., McCoy, J.T., Herries, A.I.R., Bamford, M.K., Bishop, L.C., Richmond, B.G., Kibunjia, M., 2010. Early hominin diet included diverse terrestrial and 
aquatic animals 1.95 Ma in East Turkana, Kenya. Proc. Natl. Ac. Sci. USA 107 (22): 1000210007.

Brock, A., Isaac, G.L., 1974. Paleomagnetic stratigraphy and chronology of hominid-bearing sediments east of Lake Rudolf, Kenya. Nature 247: 344-348.

Brown, F.H., Feibel, C.S., 1986. Revision of lithostratigraphic nomenclature in the Koobi Fora region, Kenya. J. Geol. Soc.13: 297-310.

Brown, F.H., Feibel, C.S., 1991. Stratigraphy, depositional environments and paleogeography of the Koobi Fora Formation. In: Harris, J.M. (ed.), Koobi Fora Research Project, Volume 3 Stratigraphy, Artiodactyls and Paleoenvironments. Clarendon Press, Oxford, pp 1-30.

Brown, F.H., McDougall, I., 2011. Geochronology of the Turkana Depression of Northern Kenya and Southern Ethiopia. Evol. Anthropol. 20 (6): 217-227.

Cerling, T.E., 1979. Paleochemistry of Plio-Pleistocene lake Turkana, Kenya. Palaeogeogr., Palaeoclim., Palaeoecol. 27: 247-285.

Chamalaum, F.H. and McDougall, I., 1966. Dating geomagnetic polarity epochs in Réunion. Nature 210: 2012-2014.

Channell, J.E.T., Guyodo, Y., 2004. The Matuyama Chronozone at ODP Site 982 (Rockall Bank): Evidence for decimeterscale magnetization lock-in depths. In: Channell et al. (Eds.), AGU Geophysical Monograph Seminar, 145: Timescales of the Geomagnetic Field, Washington DC, AGU, pp. 205-219.

de Heinzelin, J. (ed.), 1983. The Omo Group: Archives of the International Omo Research Expedition. Musée Royal de L'Afrique Centrale Tervuren, Annales Serie 8, no. 85.

deMenocal, P.B., 1995. Plio-Pleistocene African climate. Science 270: 53-59.

deMenocal, P.B., 2011. Climate and human evolution. Science 331: 540-542.

Dupont-Nivet, G., Sier, M., Campisano, C.J., Arrowsmith, J.R., DiMaggio, E., Reed, K., Lockwood, C., Franke, C., Hüsing, S., 2008. Magnetostratigraphy of the eastern Hadar Basin (Ledi-Geraru research area, Ethiopia) and implications for hominin paleoenvironments. In: Quade, J., Wynn, J.G. (eds.), The geology of early humans in the Horn of Africa. Geol. Soc. Am. Special Paper 446: 67-85.

Ellis, B.S., Mark, D.F., Pritchard, C.J., Wolff, J.A., 2012. Temporal dissection of the Huckleberry Ridge Tuff using the ${ }^{40} \mathrm{Ar} /{ }^{39} \mathrm{Ar}$ dating technique. Quatern. Geochron. 9: 34-41.

Elton, S., Bishop, L.C., Wood, B., 2001. Comparative context of Plio-Pleistocene hominin brain evolution. J. Hum. Evol. 41: 1-27.

Feibel, C.S., 1993. Freshwater stingrays from the Plio-Pleistocene of the Turkana Basin, Kenya and Ethiopia. Lethaia 26 (4): 359-366.

Feibel, C.S., 1999. Tephrostratigraphy and geological context in paleoanthropology. Evol. Anthropol. 8 (3): 87-100.

Feibel, C.S., 2011. A geological history of the Turkana Basin. Evol. Anthropol. 20 (6): 206-216.

Feibel, C.S., Brown, F.H., McDougall, I., 1989. Stratigraphic context of fossil hominids from the Omo group deposits - northern Turkana Basin, Kenya and Ethiopia. Am. J. Phys. Anthropol. 78 (4): 595-622.

Feibel, C.S., Harris, J.M., Brown, F.H., 1991. Neogene paleoenvironments of the Turkana Basin. In: Harris, J.M. (Ed.), Koobi Fora Research Project, Volume 3 Stratigraphy, Artiodactyls and Paleoenvironments, Clarendon Press, Oxford, pp. 321-370.

Gradstein, F.M., Ogg, J.G., Schmitz, M., Ogg, G. (Eds.), 2012. The Geologic Timescale 2012. Elsevier, 793 pp.

Harmon, E.H., 2009. The shape of the early hominin proximal femur. Am. J. Phys. Anthropol. 139 (2): $154-71$.

Hay, R.L., 1976. Geology of the Olduvai Gorge: a Study of Sedimentation in a Semiarid Basin. University of California Press. 
Hillhouse, J.W., Ndombi, J.W.M., Cox, A., Brock, A., 1977. Additional results on paleomagnetic stratigraphy of the Koobi Fora Formation, east of Lake Turkana (Lake Rudolf), Kenya.

Nature 265: 411-415.

Horng, C.-S., Lee, M.-Y., Pälike, H., Wei, K.-Y., Liang, W.-T., Iizuka, Y.,Torii, M., 2002. Astronomically calibrated ages for geomagnetic reversals within the Matuyama chron. Earth Planets Space 54: 679-690.

Joordens, J.C.A., Vonhof, H.B., Feibel, C.S., Lourens, L.J., Dupont-Nivet, G., van der Lubbe, H.J.L., Sier, M.J., Davies, G.R., Kroon, D., 2011. An astronomically-tuned climate framework for hominins in the Turkana Basin. Earth Planet. Sci. Lett. 307 (1-2): 1-8.

Joordens, J.C.A., Feibel, C.S., Spoor, F., Vonhof, H.B., Schulp, A., Kroon, D., 2012. A biogeographical model for hominin evolution in Africa between $\sim 5$ and $2.5 \mathrm{Ma}$. Abstract in Proceedings of the European Society for the study of Human Evolution 1: 110.

Kidane, T., Otofuji, Y.-I., Brown, F.H., Takemoto K., Eshete, G., 2007. Two normal paleomagnetic polarity intervals in the lower Matuyama Chron recorded in the Shungura Formation (Omo Valley, southwest Ethiopia). Earth Planet. Sci. Lett. 262: 240-256.

Kimbel, W.H., Walter, R.C., Johanson, D.C., Reed, K.E., Aronson, J.L., Assefa, Z., Marean, C.W., Eck, G.G., Bone, R., Hovers, E., Rak, Y., Vondra, C., Yemane, T., York, D., Chen, Y., Evensen, N.M., Smith, P.E., 1996. Late Pliocene Homo and Oldowan tools from the Hadar Formation (Kada Hadar Member), Ethiopia. J. Hum. Evol. 31: 549-561.

Kindley, C., Macho, A., Tsegaye, M.A., Feinberg, J.M., Singer, B.S., Jicha, B.R., Brown, M.C., K Birke, K.D., 2012. Paleointensity and 40Ar/39Ar geochronology of basalts at Gamarri, Ethiopia: Correlation with the Reunion subchron and Huckleberry Ridge excursion? Abstract GP13B-1128, AGU Fall Meeting 2012.

Kingdon, J., 2003. Lowly Origin: Where, When and Why Our Ancestors First Stood Up. Princeton University Press, Princeton.

Kirschvink, J.L., 1980. The least-square line and plane and the analysis of paleomagnetic data. Geophys. J. Royal Astronom. Soc. 62: 699-718.

Kuiper, K.F., Deino, A., Hilgen, F.J., Krijgsman, W., Renne, P.R., Wijbrans, J.R., 2008. Synchronizing rock clocks of Earth history. Science 320: 500-504.

Laj, C., Channell, J.E.T, 2007. Geomagnetic excursions. In: Kono, M. (Ed.), Geomagnetism, Treatise on Geophysics Volume 5, Elsevier, pp. 373-416.

Lanphere, M.A., Champion, D.E., Christiansen, R.L., Izett, G.A., Obradovich, J.D., 2002. Revised ages for tuff of the Yellowstone Plateau volcanic field: assignment of the Huckleberry Ridge Tuff to a new geomagnetic polarity event. Geol. Soc. Am. Bull. 114 (5): 559-568.

Laskar, J., Robutel, P., Joutel, F., Gastineau, M., Correia, A.C.M., Levrard, B., 2004. A long-term numerical solution for the insolation quatities of the Earth. Astron. Astrophys. 428 (1): 21285.

Leakey, M.G., Gathogo, P.N., Jablonski, N.G., 2008. Geological background and Cercopithecoid faunal assemblages. In: Jablonski, N.G., Leakey, M.G., (eds.), Koobi Fora Research Project, Volume 6 The Fossil Monkeys. The California Academy of Sciences, pp 359-396.

Leakey, M.G., Spoor, F., Dean, M.C., Feibel, C.S., Antón, S.C., Kiari, C., Leakey, L.N., 2012. New fossils from Koobi Fora in northern Kenya confirm taxonomic diversity in early Homo. Nature 488: 201-204.

Leakey, R.E.F., 1973a. Evidence for an advanced Plio-Pleistocene hominid from east Rudolf, Kenya. Nature 242: 447-450.

Leakey, R.E.F., 1973b. Further evidence of Lower Pleistocene hominids from East Rudolf, North Kenya, 1972. Nature 242: 170-173.

Leakey, R.E.F., 1974. Further evidence of Lower Pleistocene hominids from East Rudolf, North Kenya, 1973. Nature 248: 653-656. 
Lepre, C.J., Quinn, R.L., Joordens, J.C.A., Swisher, C.C., Feibel, C.S., 2007. Plio-Pleistocene facies environments from the KBS Member, Koobi Fora Formation: implications for climate controls on the development of lake-margin hominin habitats in the northeast Turkana Basin (northwest Kenya). J. Hum. Evol. 53 (5): 504-514.

Lepre, C.J., Roche, H., Kent, D.V, Harmand, S., Quinn, R.L., Brugal, J.-P., Texier, P.-J., Lenoble, A., Feibel, C.S., 2011. An earlier origin for the Acheulian. Nature 477: 82-85.

Lourens, L.J., Antonarakou, A., Hilgen, F.J., Van Hoof, A.A.M., Vergnaud-Grazzini, C., Zachariasse, W.J., 1996. Evaluation of the Plio-Pleistocene astronomical timescale. Paleoceanography 11 (4): 391-413.

Lourens, L.J., Hilgen, F.J., Shackleton, N.J., Laskar, J., Wilson, D., 2004. The Neogene period. In: Gradstein, F., Ogg, J., Smith, A.G. (eds.), A geologic timescale. Cambridge University Press, Cambridge, pp 409-430.

McDougall, I., Brown, F.H., 2006. Precise ${ }^{40} \mathrm{Ar} /{ }^{39} \mathrm{Ar}$ geochronology for the upper Koobi Fora Formation, Turkana Basin, northern Kenya. J. Geol. Soc. 163: 205-220.

McDougall, I., Brown, F.H., 2008. Geochronology of the pre-KBS Tuff sequence, Omo Group, Turkana Basin. J. Geol. Soc. 165: 549-562.

McDougall, I., Brown, F.H., Vasconcelos, P.M., Cohen, B.E., Thiede, D.S., Buchanan, M.J., 2012. New single crystal ${ }^{40} \mathrm{Ar} /{ }^{39} \mathrm{Ar}$ ages improve time scale for deposition of the Omo Group, Omo-Turkana Basin, East Africa. J. Geol. Soc. 169 (2): 213-226.

McFadden, P. L., McElhinny, M.W., 1988. The combined analysis of remagnetization circles and direct observations in paleomagnetism, Earth Plan. Sci. Letts. 87: 161-172.

McFadden, P.L., McElhinny, M.W., 1990. Classification of the reversals test in paleomagnetism. Geophys. J. Intl. 103: 725-729.

Pickering, R., Dirks, P., Jinnah, Z., de Ruiter, D.J., Churchill, S.E., Herries, A.I.R., Woodhead, J.D., Hellstrom, J.C., Berger, L.R., 2011. Australopithecus sediba at $1.977 \mathrm{Ma}$ and implications for the origins of the genus Homo. Science 333: 1421-1423.

Potts, R., 2011. Big brains explained. Nature 480: 43-44.

Quidelleur, X., Holt, J.W., Salvany, T., Bouquerel, H., 2010. New K-Ar ages from La Montagne massif, Réunion Island (Indian Ocean), supporting two geomagnetic events in the time period 2.2-2.0 Ma. Geophys. J. Int. 182: 699-710.

Richmond, B.G., Jungers, W.L., 2008. Orrorin tugenensis femoral morphology and the evolution of hominin bipedalism. Science 319: 1662-1665.

Roberts, A.P., 2008. Geomagnetic excursions: knowns and unknowns. Geophys. Res. Lett. 35, L17307, 7 pp.

Spell, T.L., McDougall, I. 2003. Characterization and calibration of ${ }^{40} \mathrm{Ar} /{ }^{39} \mathrm{Ar}$ dating standards. Chem. Geol. 198: 189-211.

Spoor, F., Leakey, M.G., Gathogo, P.N., Brown, F.H., Antón, S.C., McDougall, I., Kiarie, C., Manthi, F.K., Leakey, L.N., 2007. Implications of new early Homo fossils from Ileret, east of Lake Turkana, Kenya. Nature 448: 688-691.

Spoor, F., 2011. Malapa and the genus Homo. Nature 478: 44-45.

Suwa, G., White, T.D., Howell, F.C., 1996. Mandibular postcanine dentition from the Shungura Formation, Ethiopia: crown morphology, taxonomic allocations, and Plio-Pleistocene Hominid evolution. Am. J. Phys. Anthropol. 101: 247-282.

Talbot, M.R., Williams, M.A.J., Adamson, D.A., 2000. Strontium isotope evidence for late Pleistocene establishment of an integrated Nile drainage. Geology 28: 343-346.

Tiedemann, R., Sarnthein, M., Shackleton, N.J., 1994. Astronomic timescale for the Pliocene Atlantic $\delta^{18} \mathrm{O}$ and dust flux records of ocean drilling program site-659. Paleoceanogr. 9 (4): 619-638. 
Tuenter, E., Weber, S.L., Hilgen, F.J., Lourens, L.J., 2003. The response of the African summer monsoon to remote and local forcing due to precession and obliquity. Glob. Planet. Change 36: 219-235.

Ungar, P.S., Sponheimer, M., 2011. The diets of early hominins. Science 334: 190-193.

Van Hoof, A.A.M., Langereis, C.G., 1991. Reversal records in marine marls and delayed acquisition of remanent magnetization. Nature 351: 223-225.

Vonhof, H.B., Wesselingh, F.P., Kaandorp, R.J.G., Davies, G.R., van Hinte, J.E., Guerrero, J., Rasanen, M., Romero-Pittman, L., Ranzi, A., 2003. Paleogeography of Miocene Western Amazonia: isotopic composition of molluscan shells constrains the influence of marine incursions. Geol. Soc.Am. Bull. 115 (8): 983-993.

Vonhof, H.B., Joordens, J.C.A., Noback, M.L, van der Lubbe, H.J.L., Feibel, C.S., Kroon, D., 2013. Environmental and climatic control on seasonal stable isotope variation of freshwater molluscan bivalves in the Turkana Basin (Kenya). Palaeogeography, Palaeoclimatology, Palaeoecology doi: 10106/j.palaeo.2013.04.22.

Walter, R.C., Manega, P.C., Hay, R.L., Drake, R.E., Curtis, G.H., 1991. Laser-fusion ${ }^{40} \mathrm{Ar} /{ }^{39} \mathrm{Ar}$ dating of Bed I, Olduvai Gorge, Tanzania. Nature 354: 145-149.

Wang, P., Tian, J., Lourens, L.J., 2010. Obscuring of long eccentricity cyclicity in Pleistocene oceanic carbon isotope records. Earth Planet. Sci. Lett. 290 (3-4): 319-330.

Wood, B., 1991. Koobi Fora Research Project Volume 4: Hominid Cranial Remains. Clarendon Press, Oxford.

Wood, B., 2009. Where Does the Genus Homo Begin, and How Would We Know? In: Grine, F.E., Fleagle, J.G., Leakey, R.E. (eds.), The First Humans - Origin and Early Evolution of the Genus Homo. Springer Netherlands, pp 17-28.

Wood, B., Leakey, M.G., 2011. The Omo-Turkana Basin fossil hominins and their contribution to our understanding of human evolution in Africa. Evol. Anthropol. 20: 264-292.

\section{Captions of figures and tables}

Fig. 1. a. Location of the Turkana Basin in northeastern Africa. In red: postulated route of the

'Turkana River' connecting Turkana Basin and Indian Ocean around 2 Ma (after Feibel,

1993). b. Present-day Lake Turkana with Pliocene and Pleistocene deposits indicated in grey.

c. Location of a selection of the numbered paleontological collecting areas in the Koobi Fora

region on the northeastern coast of Lake Turkana. Dotted lines indicate ephemeral rivers.

Fig. 2. a. Sample locations within Koobi Fora Areas 131 and 105. b., c. Google earth images with detailed locations of sampled subsections (white dots) in Areas 105 and 131. Detailed information on the subsections is provided in Tables A.1 and A.2 in the Appendix. 
Fig. 3. Paleomagnetic results. a.-c. and e.-h. Representative demagnetization behaviors observed in the section of areas 105 (KS section) and 131 (KR section) respectively. Solid (open) points are projections on the horizontal (vertical) plane. d., i. Stereographic projections of ChRM directions. Solid (open) points are projections on the lower (upper) hemisphere. Mean of normal and reversed directions are indicated by larger points and given in central table (dec - declination; inc - inclination; $\mathrm{k}$ - precision parameter; a95 - 95\% confidence cone). c. Typical thermal demagnetization path (steps given in ${ }^{\circ} \mathrm{C}$ ) going to reversed direction treated by great circle analysis (McFadden and McElhinny, 1988). g. Typical AF demagnetization with biasing above 200 Oersted (see enlarged inset) interpreted to result from gyroremanence acquisition during AF treatment. h. Widely outlying direction interpreted as transitional.

Fig. 4. Overview of the paleomagnetic and Sr isotope results from Area 131 and 105. a. Timescale with periods of normal polarity in black and reversed polarity in white. Pre-O: PreOlduvai event. RU-2: second Réunion event. In grey: error bars on the ages of KBS Tuff and paleomagnetic reversals (Table 1). b. Magnetic polarity in Area 131. c. Virtual Geomagnetic Pole (VGP) latitude (in degrees) in Area 131. d. Sr isotope ratios in Area 131. e. Lithostratigraphy of the composite section in Area 131, with stratigraphic positions of hominin fossils KNM-ER 1481, KNM-ER 62000 and KNM-ER 1470 (see also Figure 5 and Table 7). f. Magnetic polarity in Area 105. g. VGP latitude (in degrees) in Area 105. h. Sr isotope ratios in Area 105. i. Lithostratigraphy of the composite section in Area 105. "GPC" and "LCC" indicates that these markerbeds are not time equivalent with the GPC and LCC beds in Area 131. Note that the F-bed in Area 105 is not the same as marker bed F in Area 131 (Table 7).

Fig. 5. Lithostratigraphic correlation of Area 131 sections, including timescale with periods of normal polarity in black and reversed polarity in white. Pre-O: Pre-Olduvai event. RU-2: 
second Réunion event. In grey: error bars on the ages of KBS Tuff and paleomagnetic reversals (Table 1); A - composite section in this study: B - composite section in Leakey (1973a). See legend of Table 4.

Fig. 6. Orbital cycles. a. Earth eccentricity, b. summer insolation at $65^{\circ} \mathrm{N}$. We apply the $65^{\circ} \mathrm{N}$ summer insolation of the La2004(1,1) astronomical solution (Laskar et al., 2004) because this target curve clearly reflects the distinct precession-obliquity interference patterns recorded by the monsoon intensity related sapropel depositions in the Mediterranean (Lourens et al., 1996; 2004).

Table A.1. Detailed information on numbered subsections in Area 105: GPS control points and stratigraphic levels of paleomagnetic samples (see Fig. 2).

Table A.2. Detailed information on numbered subsections in Area 131: GPS control points and stratigraphic levels of paleomagnetic samples (see Fig. 2).

Table 1. Overview of ages of stratigraphic levels as used in this study, tied to the astronomical timescale (Lourens et al., 2004; Gradstein et al., 2012). ${ }^{1}$ Age provided by McDougall and Brown (2006) based based on a Fish Canyon Tuff age of 28.11 Ma (Spell and McDougall, 2003). ${ }^{2}$ Age when normalized to the astronomically calibrated Fish Canyon Tuff age of 28.201 Ma (Kuiper et al., 2008). ${ }^{3}$ Horng et al., 2002. ${ }^{4}$ Channell and Gyodo, 2004. ${ }^{5}$ Age of reversal obtained by stratigraphic scaling between radiometric ages based on a Fish Canyon Tuff age of 28.11 Ma (Kidane et al., 2007). ${ }^{6}$ Radiometric age of tuff with normal polarity from Gammari, Ethiopia (Kindley et al., 2012). 
Table 2. Characteristic Remanent Magnetization (ChRM) directions from Area 105 (section KS). ID \# - Sample identification; ${ }^{\text {af }}$ - alternating field demagnetization; Level - Stratigraphic position in meters (m) with respect to base of section; Dec. - Declination; Inc. - Inclination; MAD - Maximum Angular Deviation; VGP - Virtual Geomagnetic Pole latitude; Q - Quality factor (1 - reliable direction; 2 - reliable polarity; 3 - unreliable polarity); Tinf - Lower demagnetization temperature of ChRM; Tsup - Higher demagnetization temperature of ChRM; Dir. - Direction fitting analysis (free - free line fit; forced - forced line fit; gc - great circle).

Table 3. Characteristic Remanent Magnetization (ChRM) directions from Area 131 (section KR). See caption Table 2 .

Table 4. Sr isotope data of Area 105. Sample code in italics: samples that were collected by CSF in 1986, values previously published in in Table S5 of Joordens et al. (2011).

Table 5. Sr isotope data of Area 131. Sample code in italics: sample that was collected by CSF in 1986, value prviously published in Joordens et al., 2011 (Table S5).

Table 6. Calculated sediment accumulation rates between dated markers in Areas 105 and 131: Age - reference age: KBS - KBS Tuff (dated by McDougall and Brown, 2006; age normalized according to Kuiper et al., 2008); bC2n - base of Olduvai chron (Horng et al., 2002; Lourens et al., 2004); pre-Old - pre-Olduvai event (Channel and Guyodo, 2004; Pickering et al., 2011). $\Delta$ age - analytical error in the age; Level - stratigraphic level (in bold italic if linearly exptrapolated from rate at overlying tie point); $\Delta$ Level - stratigraphic position uncertainty (in bold italic if linearly extrapolated from $\Delta$ Rate at overlying tie point); Rate - sediment 
accumulation rate derived from linear interpolation between age tie points; $\Delta$ Rate - rate uncertainty including level and age uncertainties.

Table 7. Age constraints for hominin fossils from Area 131 (Feibel et al., 1989; Wood, 1991; Wood and Leakey, 2011; Leakey et al., 2012). Rt: Right, Lt: Left. *NB In the composite section of Leakey et al. (2012) and in our composite section, KNM-ER 62000 derives from a level 21 m below KBS Tuff. In individual section CSF131-2, KNM-ER 62000 derives from KBS-17 m (Supplementary material Leakey et al., 2012). 


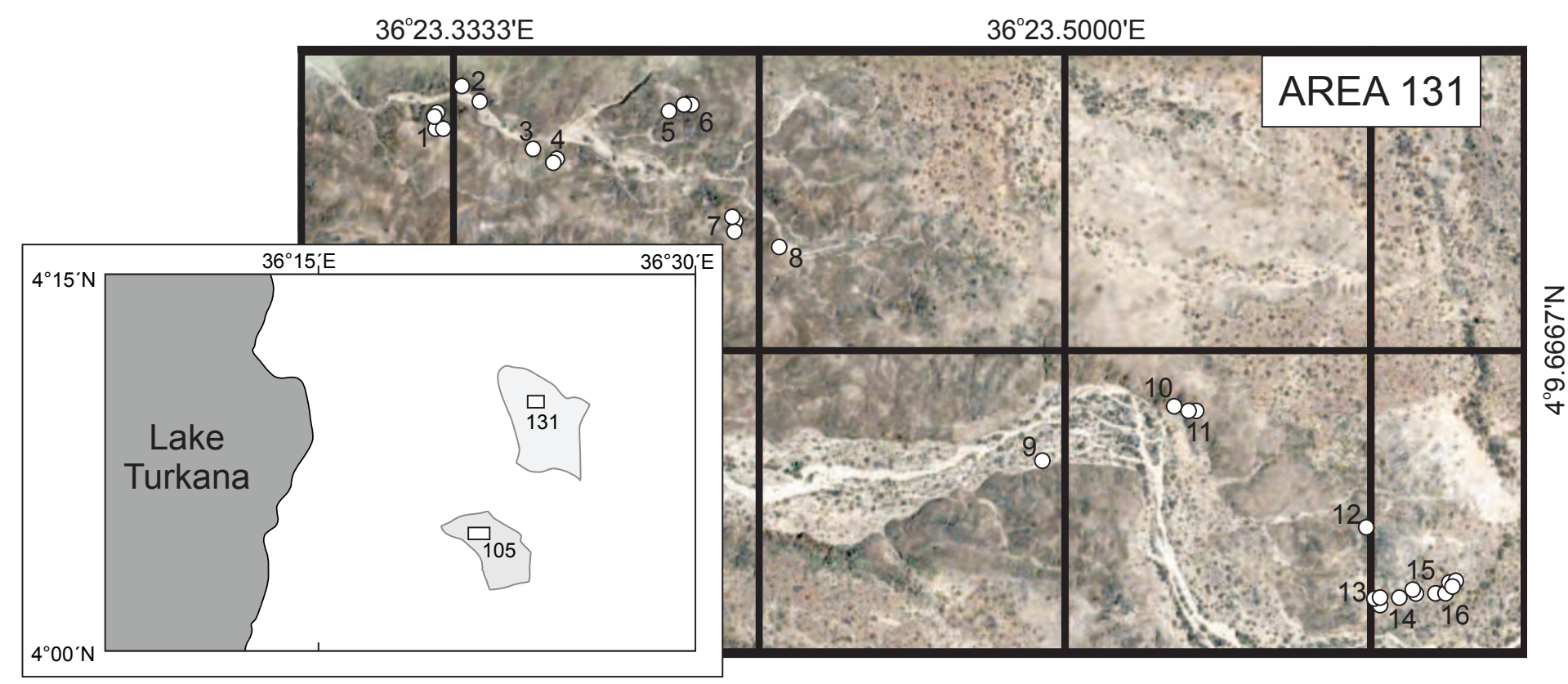

$36^{\circ} 21.0000^{\prime} \mathrm{E}$

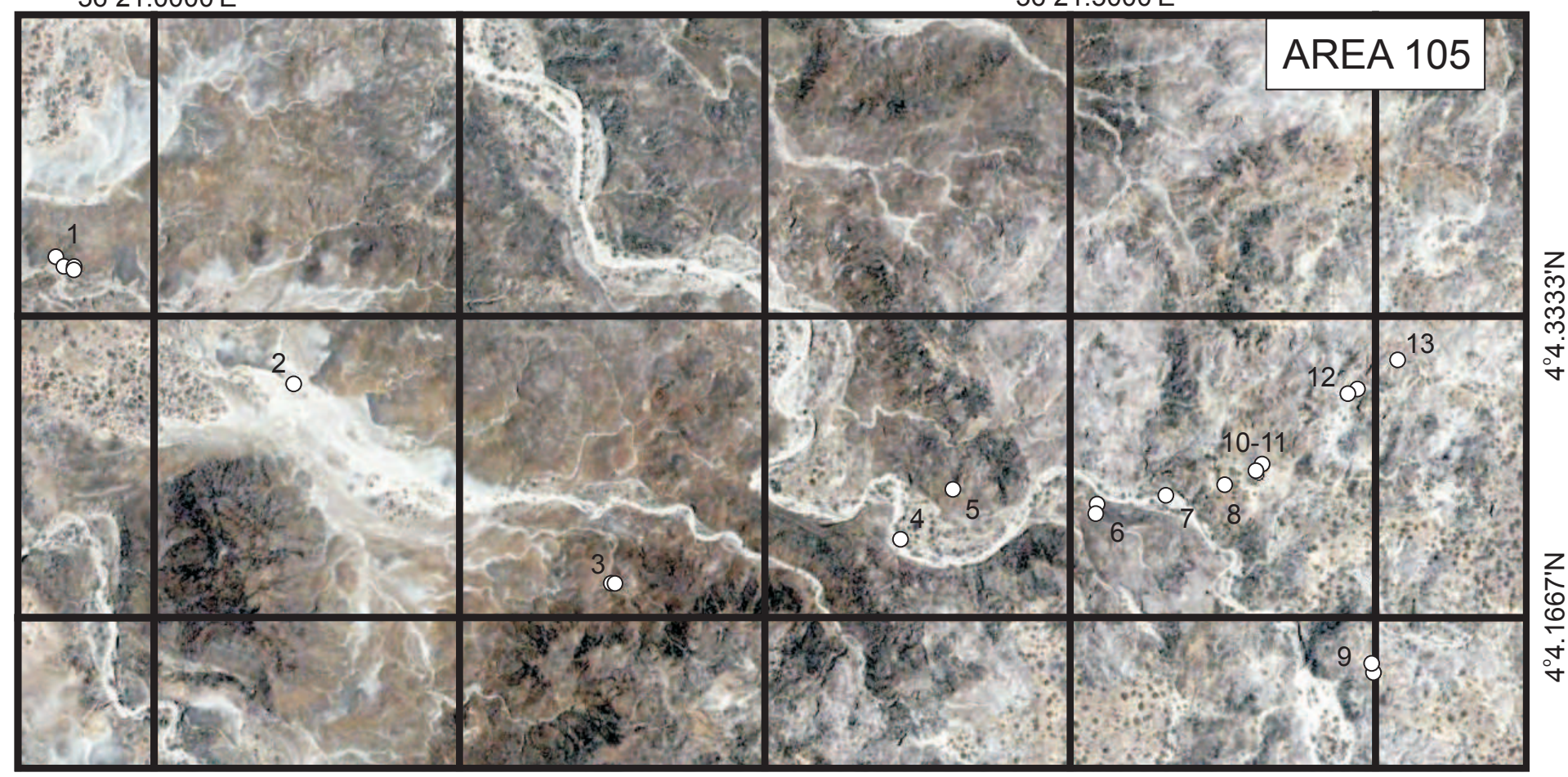




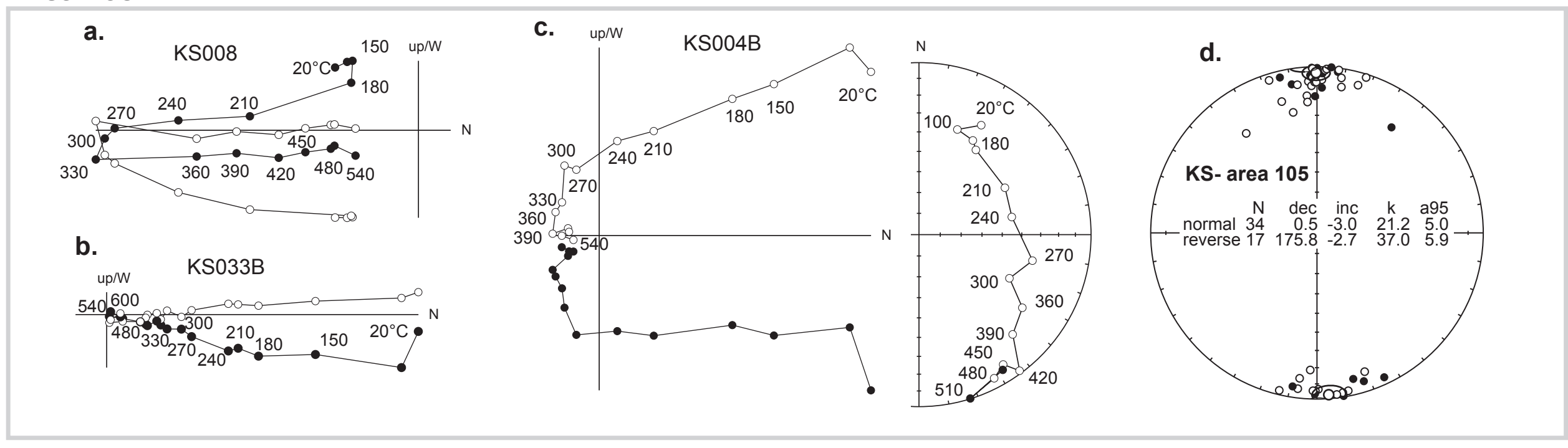

\section{Area 131}

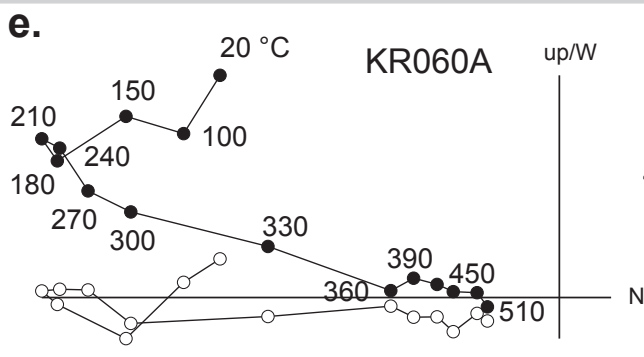

f.
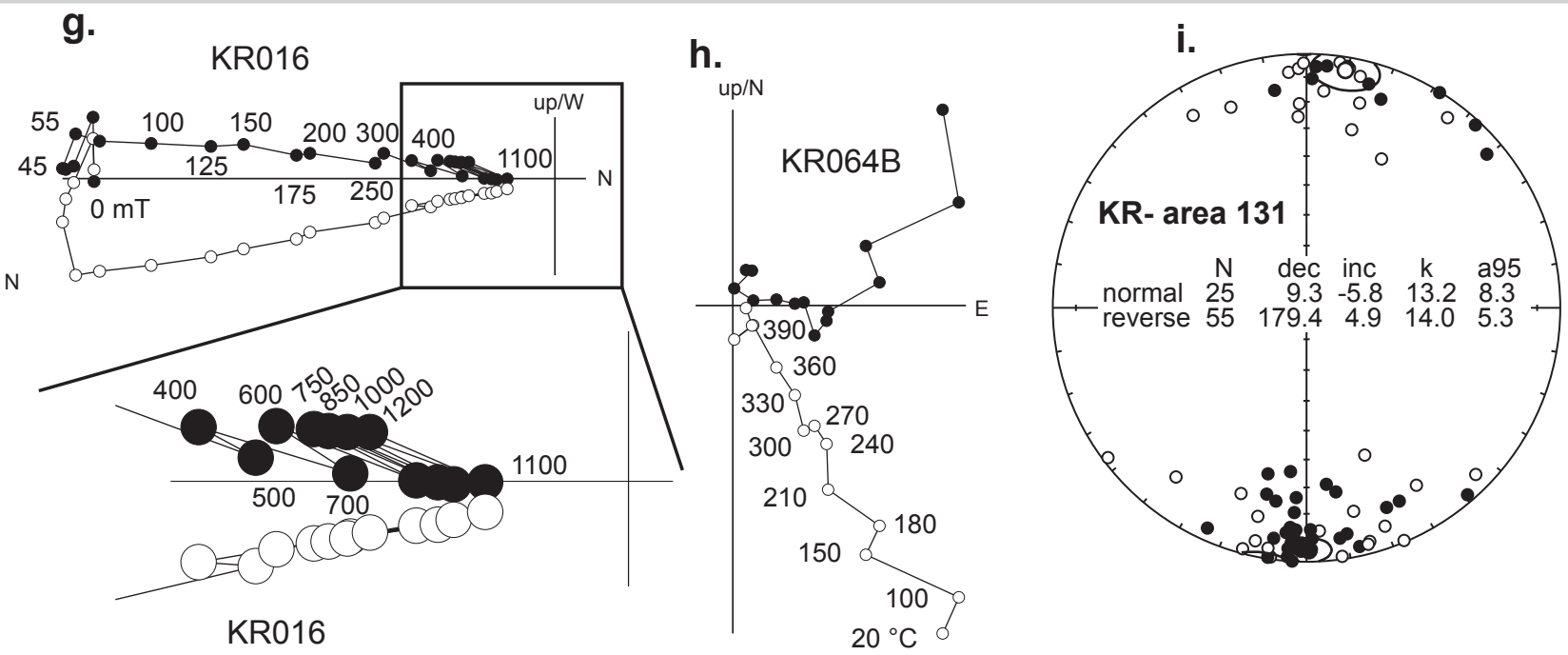


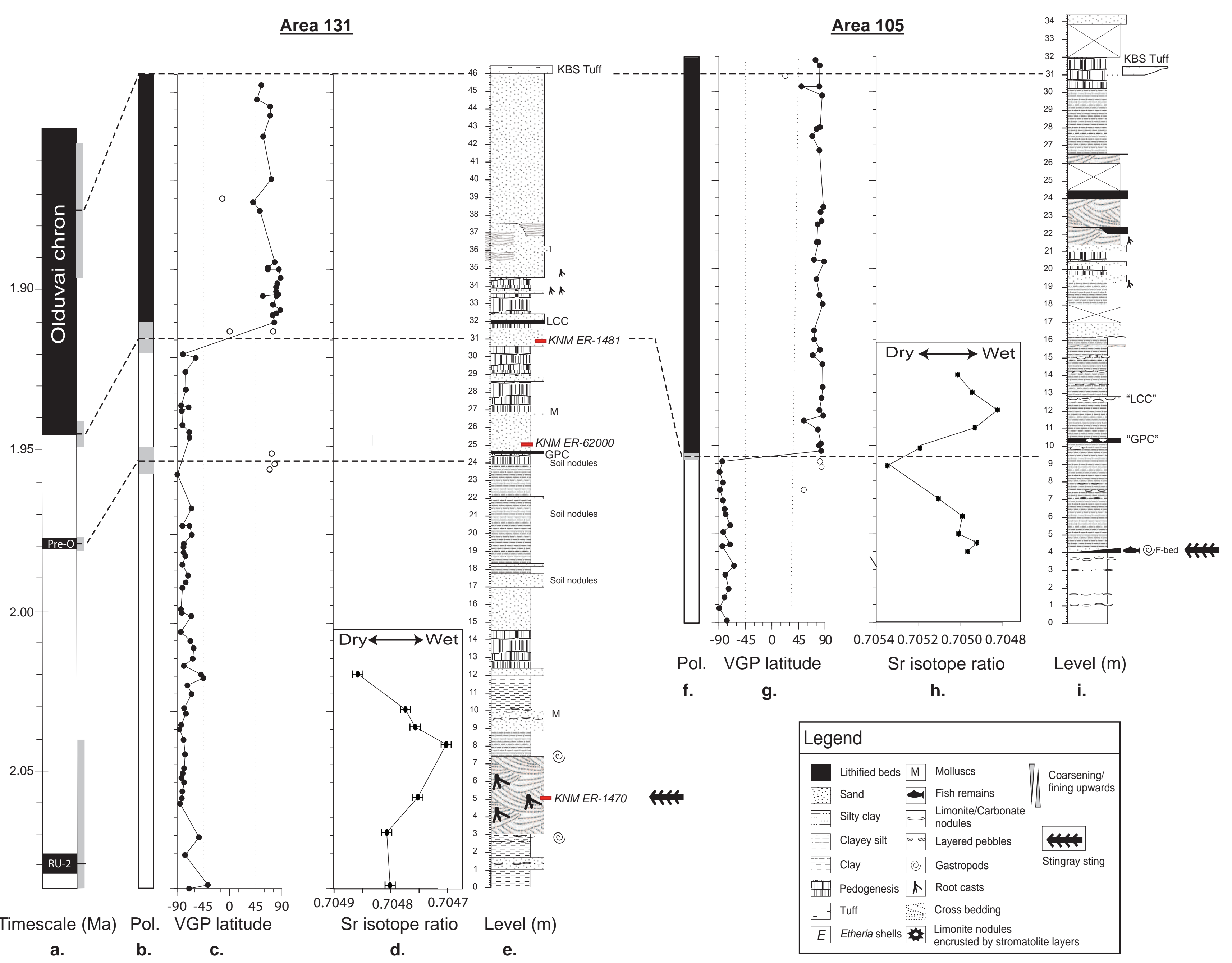




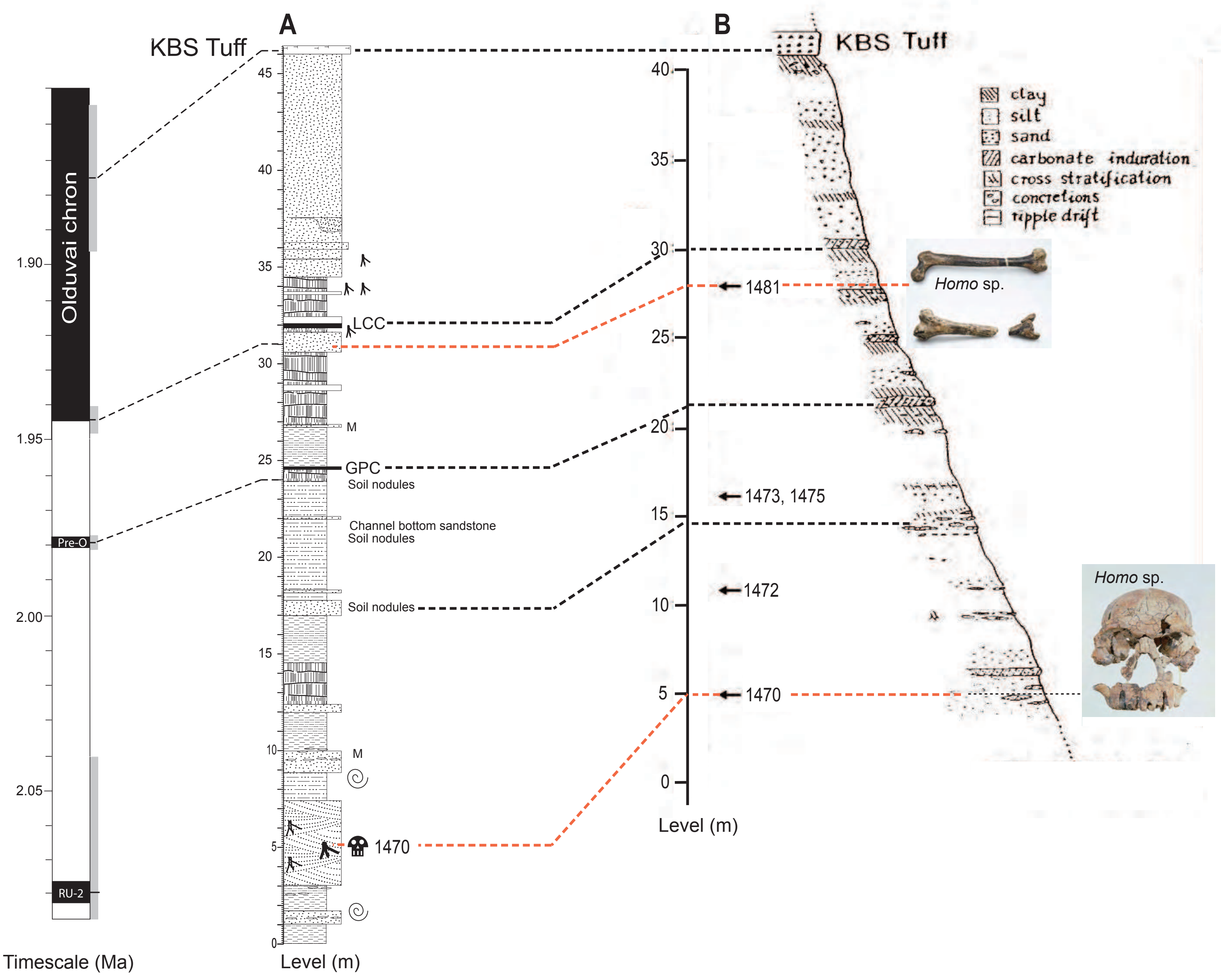



a. Eccentricity
b. Insolation $\left(\mathrm{W} / \mathrm{m}^{2}\right)$

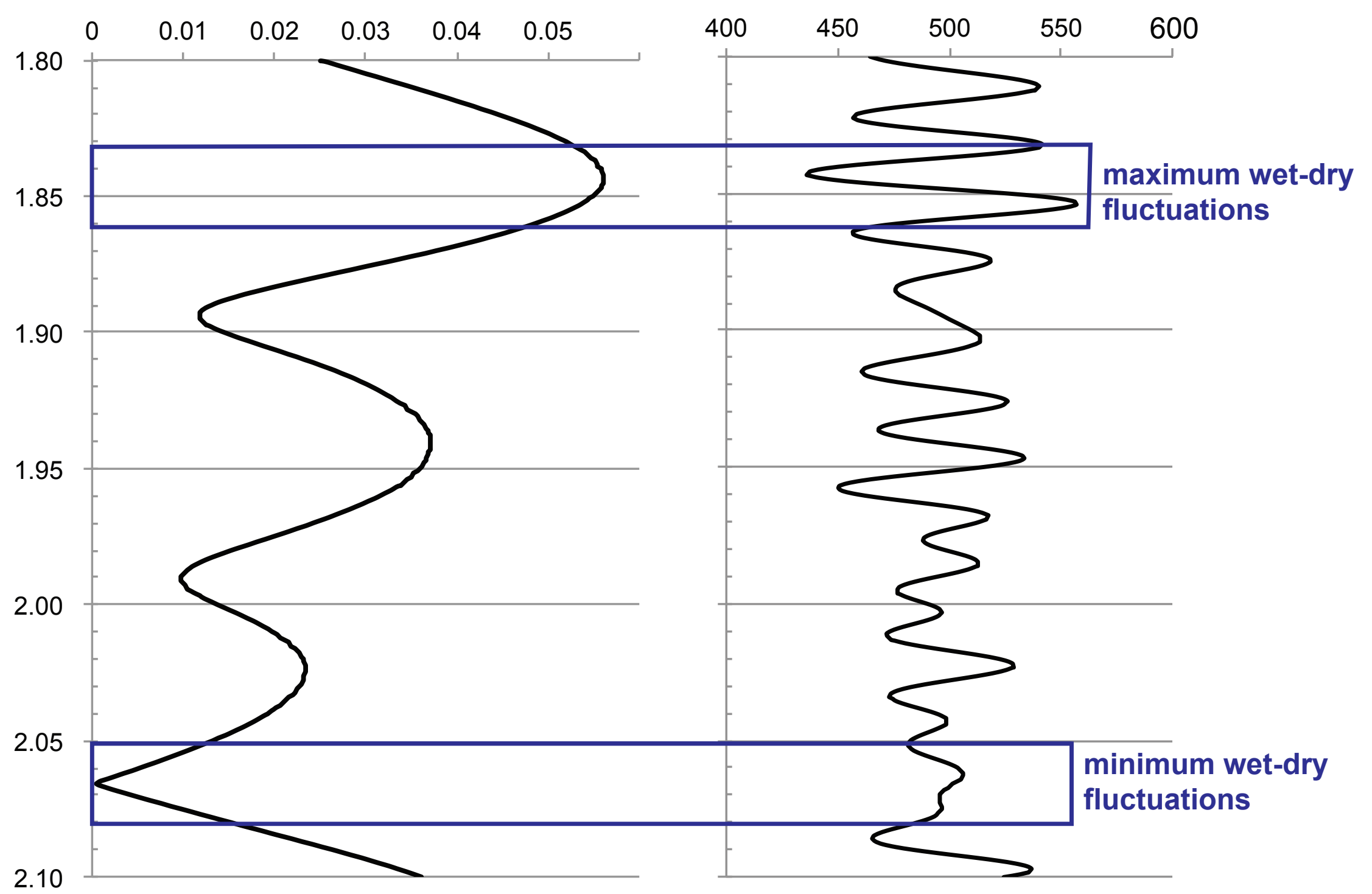




$\begin{array}{lll}\text { Name level } & \text { Radiometric age } & \text { Used in this study } \\ \text { KBS Tuff } & 1.869 \pm 0.021^{1} & 1.876 \pm 0.021^{2} \\ \text { bC2n } & & 1.945 \pm 0.004^{3} \\ \text { Pre-Olduvai event } & & 1.977 \pm 0.002^{4} \\ \text { Réunion-2 event } & 2.06 \text { to } 2.08 \pm 0.01^{5} & 2.082 \pm 0.037^{6}\end{array}$

Table 1. 


\begin{tabular}{|c|c|c|c|c|c|c|c|c|c|}
\hline ID \# & $\begin{array}{l}\text { Level } \\
\text { (m) }\end{array}$ & $\begin{array}{l}\text { Dec. } \\
\left({ }^{\circ}\right)\end{array}$ & $\begin{array}{l}\text { Inc. } \\
\left({ }^{\circ}\right)\end{array}$ & $\begin{array}{c}\text { MAD } \\
\left({ }^{\circ}\right)\end{array}$ & $\begin{array}{l}\text { VGP } \\
\left({ }^{\circ}\right)\end{array}$ & $\mathbf{Q}$ & $\begin{array}{l}\text { Tinf } \\
\left({ }^{\circ} \mathrm{C}\right)\end{array}$ & $\begin{array}{l}\text { Tsup } \\
\left({ }^{\circ} \mathrm{C}\right)\end{array}$ & Dir. \\
\hline SO63 & 31.8 & 355.9 & -22.1 & 10.5 & 74.0 & 1 & 150 & 570 & free \\
\hline S062 & 31.5 & 1.9 & -8.6 & 14.9 & 81.5 & 1 & 240 & 420 & free \\
\hline is061* & 30.9 & 66.7 & -3.5 & 8.2 & 23.1 & 3 & 180 & 600 & free \\
\hline is060B & 30.3 & 356.8 & -9.6 & 13.5 & 50.3 & 1 & 210 & 420 & free \\
\hline is060A & 30.3 & 324.6 & -27.4 & 4.2 & 80.6 & 1 & 210 & 450 & free \\
\hline is059A & 29.8 & 358.5 & -1.2 & 19.3 & 85.2 & 1 & 240 & 420 & free \\
\hline is057 & 28.0 & 358.3 & -7.3 & 16.0 & 82.1 & 1 & 180 & 400 & free \\
\hline S056 & 27.9 & 9.5 & -12.0 & 17.4 & 76.2 & 1 & 150 & 510 & free \\
\hline SO55 & 27.5 & 348.9 & -27.0 & 9.8 & 68.7 & 1 & 180 & 570 & free \\
\hline is054 & 26.7 & 359.1 & -10.2 & 9.6 & 80.8 & 1 & 180 & 570 & free \\
\hline $\mathrm{SS} 052^{\mathrm{af}}$ & 23.5 & 357.6 & 5.6 & 11.4 & 87.3 & 1 & 100 & 500 & free \\
\hline is051A & 23.2 & 0.9 & -6.0 & 25.5 & 82.9 & 1 & 180 & 480 & free \\
\hline is049 & 22.7 & 359.2 & 18.9 & 20.3 & 84.2 & 1 & 210 & 510 & free \\
\hline S048 & 22.5 & 352.5 & -11.1 & 6.8 & 77.8 & 1 & 180 & 450 & free \\
\hline is042 & 21.5 & 357.9 & -12.4 & 18.2 & 76.5 & 1 & 240 & 400 & free \\
\hline $\mathrm{SS} 044^{\text {af }}$ & 21.5 & 346.6 & 4.4 & 1.4 & 79.5 & 1 & 45 & 600 & free \\
\hline SO40 & 20.5 & 342.6 & -4.4 & 5.8 & 71.5 & 1 & 210 & 510 & free \\
\hline is039 & 20.4 & 359.2 & 9.1 & 10.6 & 89.0 & 1 & 180 & 420 & free \\
\hline is038A & 19.4 & 355.8 & -18.4 & 10.0 & 75.9 & 1 & 210 & 360 & free \\
\hline SO37A & 18.5 & 359.8 & -10.1 & 13.4 & 80.9 & 1 & 180 & 540 & free \\
\hline$\left(S 036 A^{\text {af }}\right.$ & 18.0 & 0.1 & 0.8 & 2.1 & 86.4 & 1 & 75 & 500 & free \\
\hline S034A & 16.5 & 17.6 & -2.1 & 6.7 & 71.7 & 1 & 210 & 450 & free \\
\hline SO33B & 16.0 & 15.6 & -8.6 & 6.6 & 72.3 & 1 & 240 & 400 & free \\
\hline SO31A & 15.4 & 7.4 & 2.6 & 11.3 & 82.1 & 1 & 240 & 450 & free \\
\hline SO32 & 15.1 & 345.0 & -19.3 & 4.8 & 69.6 & 1 & 180 & 450 & free \\
\hline SS030A & 14.6 & 358.2 & 0.7 & 11.7 & 85.9 & 1 & 240 & 450 & free \\
\hline SO28 & 13.3 & 2.0 & 13.6 & 4.1 & 86.5 & 1 & 75 & 600 & free \\
\hline S027 & 12.7 & 3.4 & -1.4 & 6.2 & 84.2 & 1 & 180 & 510 & free \\
\hline KS026 & 12.0 & 7.7 & -1.2 & 13.1 & 81.0 & 1 & 270 & 540 & free \\
\hline SO25 & 11.7 & 2.0 & 4.5 & 12.0 & 87.3 & 1 & 240 & 540 & free \\
\hline S024 & 11.4 & 35.2 & 23.3 & 11.3 & 54.2 & 1 & 20 & 450 & free \\
\hline S023 & 10.9 & 9.0 & -6.3 & 5.7 & 78.5 & 1 & 210 & 480 & free \\
\hline SO22 & 10.1 & 5.0 & 0.0 & 12.4 & 83.6 & 1 & 240 & 400 & free \\
\hline iS014A & 10.0 & 350.4 & 10.3 & 12.9 & 80.4 & 1 & 240 & 420 & free \\
\hline is015B & 9.7 & 2.9 & -2.2 & 5.0 & 84.1 & 2 & 150 & 420 & forced \\
\hline is016A & 9.1 & 356.4 & 21.6 & 11.3 & -83.8 & 3 & 240 & 380 & free \\
\hline is016B & 9.1 & 182.8 & -18.5 & 9.8 & 82.0 & 2 & 210 & 450 & $\mathrm{gc}$ \\
\hline is017B & 8.8 & 5.7 & 8.6 & 5.4 & 84.3 & 3 & 0 & 340 & free \\
\hline is018B & 8.5 & 180.5 & -5.5 & 25.5 & -88.7 & 2 & 100 & 480 & $\mathrm{gc}$ \\
\hline is019B & 7.9 & 186.8 & -12.9 & 23.3 & -82.8 & 2 & 180 & 450 & gc \\
\hline is020A & 7.5 & 181.4 & -5.5 & 18.8 & -88.1 & 2 & 0 & 340 & $\mathrm{gc}$ \\
\hline is020B & 7.5 & 35.5 & 10.3 & 7.2 & 54.6 & 3 & 210 & 360 & free \\
\hline is021 & 6.9 & 187.0 & -6.2 & 19.3 & -83.0 & 2 & 100 & 480 & $\mathrm{gc}$ \\
\hline S013 & 6.4 & 170.7 & 0.6 & 9.1 & -79.8 & 1 & 240 & 570 & free \\
\hline S012 & 6.1 & 189.0 & 7.2 & 7.1 & -78.2 & 1 & 330 & 510 & free \\
\hline KS011 & 5.5 & 162.4 & 7.1 & 11.4 & -70.9 & 1 & 210 & 450 & free \\
\hline is010 & 5.1 & 173.0 & -2.3 & 14.7 & -82.4 & 1 & 240 & 570 & free \\
\hline is009A & 4.4 & 161.0 & -12.7 & 11.5 & -70.9 & 1 & 210 & 540 & free \\
\hline is008 & 4.3 & 180.7 & 3.7 & 5.7 & -84.1 & 1 & 330 & 510 & free \\
\hline is006B & 3.2 & 155.0 & 4.7 & 23.2 & -64.2 & 2 & 270 & 38 & forced \\
\hline is005A & 2.7 & 168.8 & -3.5 & 22.4 & -78.6 & 2 & 350 & 450 & forced \\
\hline S004B & 1.9 & 166.0 & 10.4 & 12.1 & -73.2 & 2 & 100 & 450 & $\mathrm{gc}$ \\
\hline SS003A & 1.4 & 170.8 & -2.9 & 18.5 & -80.5 & 2 & 280 & 510 & forced \\
\hline S002 & 0.8 & 179.5 & -6.5 & 16.9 & -89.1 & 2 & 270 & 310 & \\
\hline S001 & 0.1 & 193.4 & -2.9 & 15.8 & -76.4 & 1 & 300 & 510 & \\
\hline verages & $\mathbf{N}$ & Dec. & Inc. & $\alpha 95$ & & & Tinf & Tsup & \\
\hline
\end{tabular}




$\begin{array}{ccccc} & & \left(^{\circ}\right) & \left(^{\circ}\right) & \left(^{\circ}\right) \\ \text { Mean N } & 34 & 0.5 & 3.0 & 5.0 \\ \text { Mean R } & 17 & 175.8 & -2.7 & 5.9\end{array}$

$\left({ }^{\circ} \mathrm{C}\right) \quad\left({ }^{\circ} \mathrm{C}\right)$

193463

Table 2. 


\begin{tabular}{|c|c|c|c|c|c|c|c|c|c|}
\hline ID \# & $\begin{array}{c}\text { Level } \\
(m)\end{array}$ & $\begin{array}{c}\text { Dec. } \\
\left({ }^{\circ}\right)\end{array}$ & $\begin{array}{l}\text { Inc. } \\
\left({ }^{\circ}\right)\end{array}$ & $\begin{array}{c}\text { MAD } \\
\left({ }^{\circ}\right)\end{array}$ & $\begin{array}{l}\text { VGP } \\
\left({ }^{\circ}\right)\end{array}$ & $\mathbf{Q}$ & $\begin{array}{l}\text { Tinf } \\
\left({ }^{\circ} \mathrm{C}\right)\end{array}$ & $\begin{array}{l}\text { Tsup } \\
\left({ }^{\circ} \mathrm{C}\right)\end{array}$ & Dir. \\
\hline KR082 & 45.4 & 26.8 & -34.6 & 8.8 & 55.0 & 1 & 210 & 390 & free \\
\hline KR083 & 44.6 & 42.8 & 2.2 & 11.0 & 47.2 & 2 & 150 & 450 & forced \\
\hline KR084 & 44.2 & 19.7 & 13.8 & 12.0 & 70.2 & 1 & 180 & 360 & free \\
\hline KR085 & 43.7 & 14.6 & -17.8 & 8.5 & 70.4 & 1 & 180 & 450 & free \\
\hline KR087 & 42.5 & 31.8 & 0.4 & 17.7 & 58.0 & 1 & 150 & 390 & free \\
\hline KR092 & 40.1 & 357.5 & -25.6 & 19.2 & 72.4 & 2 & 150 & 330 & forced \\
\hline KR093 & 39.0 & 250.8 & -75.9 & 8.9 & -12.1 & 3 & 150 & 390 & free \\
\hline KR094 & 38.8 & 49.6 & 7.3 & 12.9 & 40.5 & 2 & 340 & 480 & forced \\
\hline KR095 & 38.3 & 36.6 & -7.5 & 11.2 & 52.6 & 1 & 240 & 480 & free \\
\hline KR081 & 35.4 & 10.2 & -4.7 & 8.8 & 78.0 & 1 & 150 & 450 & free \\
\hline KR073 & 35.1 & 339.4 & -16.7 & 24.4 & 65.9 & 1 & 270 & 510 & free \\
\hline KR080 & 35.0 & 4.9 & 4.9 & 3.6 & 84.9 & 1 & 180 & 510 & free \\
\hline KR072 & 35.0 & 14.3 & -28.5 & 9.4 & 66.2 & 1 & 180 & 540 & free \\
\hline KR079 & 34.5 & 1.4 & 10.6 & 19.5 & 88.1 & 1 & 270 & 380 & free \\
\hline KR071 & 34.2 & 358.1 & -6.4 & 8.2 & 82.5 & 1 & 150 & 540 & free \\
\hline KR078 & 34.0 & 9.7 & 3.9 & 12.2 & 80.1 & 1 & 270 & 510 & free \\
\hline KR077A & 33.8 & 7.8 & -2.8 & 8.9 & 80.5 & 1 & 150 & 480 & free \\
\hline KR070 & 33.6 & 359.3 & -4.1 & 18.9 & 83.9 & 1 & 270 & 450 & free \\
\hline KR069 & 33.5 & 355.7 & -7.7 & 13.3 & 81.0 & 1 & 180 & 510 & free \\
\hline KR076 & 33.5 & 329.5 & -13.2 & 14.3 & 57.7 & 2 & 150 & 420 & forced \\
\hline KR068 & 33.0 & 13.1 & -7.1 & 9.4 & 74.9 & 1 & 180 & 510 & free \\
\hline KR067 & 32.7 & 2.3 & 5.5 & 11.2 & 87.4 & 1 & 150 & 420 & free \\
\hline KR066 & 32.5 & 351.7 & 14.6 & 6.5 & 81.1 & 1 & 150 & 320 & free \\
\hline KR065B & 32.4 & 15.6 & 9.4 & 7.8 & 74.4 & 1 & 150 & 340 & free \\
\hline KR074A & 32.0 & 4.6 & -15.4 & 7.6 & 77.3 & 1 & 150 & 450 & free \\
\hline KR064B & 31.5 & 93.0 & 63.6 & 4.2 & 0.7 & 3 & 300 & 450 & free \\
\hline KR064A & 31.5 & 358.0 & -20.7 & 21.3 & 75.2 & 3 & 240 & 400 & free \\
\hline KR063B & 30.2 & 183.2 & 10.9 & 8.7 & -80.0 & 1 & 210 & 600 & free \\
\hline KR062 & 30.0 & 148.2 & -18.9 & 18.9 & -57.9 & 2 & 240 & 360 & forced \\
\hline KR061B & 29.2 & 166.9 & -18.8 & 11.3 & -75.8 & 1 & 240 & 600 & free \\
\hline KR060A & 28.2 & 194.8 & -2.1 & 4.4 & -74.9 & 1 & 270 & 510 & free \\
\hline KR060B & 28.2 & 165.3 & -4.2 & 24.0 & -75.2 & 1 & 240 & 450 & free \\
\hline KR059A & 27.3 & 182.5 & 5.8 & 10.8 & -82.7 & 2 & 100 & 270 & $\mathrm{gc}$ \\
\hline KR059B & 27.2 & 160.2 & -9.5 & 19.1 & -70.2 & 2 & 210 & 600 & forced \\
\hline KR058 & 27.0 & 181.1 & 8.2 & 22.1 & -81.8 & 2 & 20 & 270 & $\mathrm{gc}$ \\
\hline KR057B & 26.2 & 171.8 & -1.3 & 15.2 & -81.1 & 1 & 320 & 570 & free \\
\hline KR056 ${ }^{\text {af }}$ & 25.8 & 170.9 & 27.4 & 16.1 & -69.4 & 2 & 25 & 100 & $\mathrm{gc}$ \\
\hline KR055B & 25.5 & 192.0 & 25.9 & 17.7 & -68.7 & 1 & 420 & 570 & free \\
\hline KR054 & 24.6 & 14.8 & 25.4 & 5.4 & 72.6 & 3 & 150 & 320 & free \\
\hline KR053 & 24.0 & 347.6 & 7.1 & 15.2 & 77.6 & 3 & 150 & 480 & free \\
\hline $\operatorname{RR} 052^{\mathrm{af}}$ & 23.7 & 20.7 & 1.5 & 5.1 & 69.1 & 3 & 75 & 500 & free \\
\hline KR051 & 23.4 & 180.3 & -7.0 & 27.3 & -89.4 & 2 & 180 & 360 & forced \\
\hline KR049B & 21.5 & 204.2 & 5.5 & 11.7 & -64.9 & 1 & 240 & 570 & free \\
\hline KR048B & 20.5 & 173.5 & 30.7 & 9.1 & -68.5 & 1 & 240 & 510 & free \\
\hline KR048A & 20.5 & 183.6 & 8.2 & 8.7 & -81.1 & 1 & 270 & 480 & free \\
\hline KR048A & 20.5 & 183.6 & 8.2 & 8.7 & -81.1 & 1 & 270 & 480 & free \\
\hline KR047A & 20.0 & 193.0 & 33.3 & 8.5 & -64.4 & 1 & 240 & 480 & free \\
\hline KR046 & 19.5 & 188.1 & 9.2 & 8.7 & -78.2 & 1 & 210 & 480 & free \\
\hline KR045 & 19.3 & 178.9 & 13.7 & 11.2 & -79.0 & 1 & 210 & 390 & free \\
\hline KR044 ${ }^{\text {af }}$ & 19.0 & 182.7 & 13.4 & 30.0 & -78.9 & 2 & 75 & 600 & forced \\
\hline KR043A & 18.8 & 167.4 & 4.1 & 9.9 & -76.0 & 1 & 210 & 420 & free \\
\hline KR042 & 18.3 & 189.1 & -4.7 & 11.1 & -80.8 & 1 & 210 & 390 & free \\
\hline KR041A & 17.7 & 189.0 & 24.0 & 12.6 & -71.2 & 1 & 180 & 390 & free \\
\hline KR040 & 17.3 & 183.4 & 20.3 & 6.8 & -75.1 & 1 & 240 & 390 & free \\
\hline KR039 & 17.0 & 178.6 & 9.9 & 18.0 & -80.9 & 1 & 240 & 390 & free \\
\hline KR038 & 15.8 & 184.4 & 2.0 & 7.3 & -83.3 & 2 & 100 & 360 & $\mathrm{gc}$ \\
\hline
\end{tabular}




\begin{tabular}{|c|c|c|c|c|c|c|c|c|c|}
\hline KR037 & 15.6 & 181.6 & 8.0 & 9.0 & -81.8 & 2 & 100 & 320 & $\mathrm{gc}$ \\
\hline $\mathrm{KR} 036^{\text {af }}$ & 15.4 & 185.5 & 35.5 & 1.7 & -65.8 & 1 & 100 & 700 & free \\
\hline KR035 & 14.5 & 181.3 & 4.6 & 17.8 & -83.6 & 2 & 100 & 320 & $\mathrm{gc}$ \\
\hline KR034 & 14.0 & 157.2 & -0.7 & 15.0 & -66.9 & 1 & 320 & 460 & free \\
\hline KR033 & 13.6 & 154.3 & 16.6 & 16.0 & -61.5 & 1 & 270 & 460 & free \\
\hline KR032 & 13.0 & 158.4 & -37.7 & 13.4 & -62.9 & 1 & 270 & 510 & free \\
\hline KR031 & 12.6 & 183.6 & 13.8 & 5.0 & -78.4 & 2 & 20 & 270 & $\mathrm{gc}$ \\
\hline KR030 & 12.1 & 139.2 & 3.1 & 11.6 & -48.8 & 1 & 210 & 420 & free \\
\hline KR029 & 11.9 & 134.5 & -7.1 & 9.1 & -44.6 & 2 & 210 & 420 & forced \\
\hline KR028 & 11.5 & 183.1 & 26.1 & 17.0 & -72.0 & 2 & 20 & 300 & $\mathrm{gc}$ \\
\hline KR027 & 11.0 & 158.1 & 16.4 & 22.9 & -64.9 & 2 & 300 & 420 & free \\
\hline KR024 & 10.2 & 184.2 & 14.3 & 8.3 & -78.0 & 2 & 100 & 360 & $\mathrm{gc}$ \\
\hline KR023 & 9.9 & 164.8 & -5.2 & 25.9 & -74.8 & 1 & 270 & 480 & free \\
\hline KR020 & 9.3 & 181.6 & 5.5 & 7.1 & -83.1 & 2 & 20 & 270 & $\mathrm{gc}$ \\
\hline KR019 & 9.0 & 176.7 & -13.0 & 19.9 & -85.8 & 2 & 180 & 420 & forced \\
\hline $\mathrm{KR} 016^{\text {af }}$ & 8.4 & 185.2 & 12.2 & 2.9 & -78.6 & 1 & 75 & 1200 & free \\
\hline KR012 & 7.6 & 169.8 & 10.5 & 4.3 & -76.2 & 1 & 240 & 510 & free \\
\hline KR008 & 6.8 & 171.7 & 9.2 & 8.2 & -78.0 & 1 & 180 & 360 & free \\
\hline KR007 & 6.5 & 188.8 & 0.7 & 4.9 & -80.2 & 2 & 100 & 320 & $\mathrm{gc}$ \\
\hline KR006 & 6.3 & 181.4 & 7.1 & 3.4 & -82.3 & 2 & 270 & 510 & $\mathrm{gc}$ \\
\hline KR005B & 6.0 & 192.4 & -6.8 & 12.6 & -77.6 & 1 & 210 & 360 & free \\
\hline KR011 & 5.5 & 188.2 & -1.0 & 6.7 & -81.1 & 2 & 210 & 360 & $\mathrm{gc}$ \\
\hline KR010A & 5.1 & 184.4 & 5.5 & 1.8 & -81.9 & 2 & 210 & 510 & $\mathrm{gc}$ \\
\hline KR009A & 4.8 & 183.2 & 0.1 & 13.4 & -84.8 & 2 & 300 & 510 & forced \\
\hline KR004B & 2.9 & 217.6 & -17.0 & 2.0 & -52.4 & 1 & 300 & 510 & free \\
\hline KR003A & 1.9 & 193.1 & -16.8 & 2.9 & -76.2 & 1 & 240 & 480 & free \\
\hline KR002 & 0.2 & 233.0 & -2.3 & 7.3 & -37.0 & 2 & 240 & 450 & forced \\
\hline KR001A & 0.0 & 199.4 & -23.5 & 7.4 & -69.1 & 1 & 210 & 420 & free \\
\hline Averages & $\mathrm{n}$ & $\begin{array}{c}\text { Dec. } \\
\left({ }^{\circ}\right)\end{array}$ & $\begin{array}{l}\text { Inc. } \\
\left({ }^{\circ}\right)\end{array}$ & $\begin{array}{c}\alpha 95 \\
\left({ }^{\circ}\right)\end{array}$ & & & $\begin{array}{l}\text { Tinf } \\
\left({ }^{\circ} \mathrm{C}\right)\end{array}$ & $\begin{array}{l}\text { Tsup } \\
\left({ }^{\circ} \mathrm{C}\right)\end{array}$ & \\
\hline Mean N & 25 & 9.3 & -5.8 & 8.3 & & & 190 & 444 & \\
\hline Mean R & 55 & 179.4 & 4.9 & 53 & & & & & \\
\hline
\end{tabular}

Table 3. 


$\begin{array}{llrcc}\text { Sample code } & \text { Sample type } & \text { Strat. level }(\mathbf{m}) & { }^{87} \mathbf{S r}{ }^{86} \mathbf{S r} & \text { Standard error }(\mathbf{2} \boldsymbol{\sigma}) \\ 10 \text { KS-14 } & \text { fish bone } & 14 & 0.705015 & 0.000009 \\ \text { K86-2380 } & \text { stingray sting } & 13 & 0.704946 & 0.000008 \\ \text { K86-2381 } & \text { stingray sting } & 12 & 0.704826 & 0.000008 \\ \text { K86-2397 } & \text { fish tooth } & 11 & 0.704932 & 0.000008 \\ 10 \text { KS-10 } & \text { fish bone } & 10 & 0.705194 & 0.000011 \\ 10 K S-9 & \text { fish bone } & 9 & 0.705350 & 0.000015 \\ 10 K S-7 & \text { fish tooth } & 7 & 0.705107 & 0.000010 \\ 10 K S-6 & \text { fish bone } & 6 & 0.704992 & 0.000010 \\ 10 K S-5 & \text { fish bone } & 5 & 0.705010 & 0.000009 \\ \text { K86-2382+ } & \text { stingray sting } & 4.5 & 0.704924 & 0.000008 \\ \text { K86-2382 } & \text { stingray sting } & 4 & 0.704967 & 0.000009\end{array}$

Table 4. 


$\begin{array}{llrrc}\text { Sample code } & \text { Sample type } & \text { Level }(\mathbf{m}) & { }^{87} \mathbf{S r} /{ }^{86} \mathbf{S r} & \text { Standard error }(\mathbf{2} \boldsymbol{\sigma}) \\ \text { KJ10-10 } & \text { Sindacharax tooth } & 33.5 & 0.705022 & 0.000011 \\ 10 \text { KR-29 } & \text { fish bones } & 29 & 0.704979 & 0.000008 \\ 10 \text { KR-22 } & \text { fish tooth } & 22 & 0.704966 & 0.000010 \\ 10 \text { KR-20 } & \text { fish tooth } & 20 & 0.704942 & 0.000008 \\ 10 \text { KR-12 } & \text { Distichodus tooth } & 12 & 0.704872 & 0.000012 \\ 10 \text { KR-10 } & \text { fish bones } & 10 & 0.704788 & 0.000008 \\ 10 K R-9 & \text { Distichodus tooth } & 9 & 0.704771 & 0.000009 \\ 10 K R-8 & \text { fish bones } & 8 & 0.704716 & 0.000008 \\ \text { K86-2278 } & \text { stingray spine } & 5 & 0.704759 & 0.000009 \\ 10 K R-5 & \text { fish bones } & 5 & 0.704766 & 0.000009 \\ 10 K R-3 & \text { fish bones } & 3 & 0.704821 & 0.000009 \\ 10 K R-0 & \text { fish bones } & 0 & 0.704815 & 0.000009\end{array}$

Table 5. 


\begin{tabular}{|c|c|c|c|c|c|c|c|c|c|c|c|c|c|c|c|}
\hline \multirow{3}{*}{ Marker } & \multicolumn{3}{|c|}{ Reference } & \multicolumn{6}{|c|}{ Area 105} & \multicolumn{6}{|c|}{ Area 131} \\
\hline & Age & \pm & $\Delta$ age & Level & \pm & $\Delta$ level & Rate & \pm & $\Delta$ rate & Level & \pm & $\Delta$ level & Rate & \pm & $\Delta$ rate \\
\hline & (ka) & & (kyr) & $(\mathrm{cm})$ & & $(\mathrm{cm})$ & (cm/kyr) & & (cm/kyr) & $(\mathrm{cm})$ & & $(\mathrm{cm})$ & (cm/kyr) & & $(\mathrm{cm} / \mathrm{kyr})$ \\
\hline KBS & 1876 & \pm & 21 & 3100 & \pm & 0.0 & 31.3 & \pm & 9.2 & 4600 & \pm & 0 & 21.6 & \pm & 7.2 \\
\hline$b C 2 n$ & 1945 & \pm & 4 & 940 & \pm & 30.0 & & & & 3110 & \pm & 90 & 21.7 & \pm & 5.1 \\
\hline pre-Old & 1977 & \pm & 2 & -61.7 & \pm & 116.9 & & & & 2415 & \pm & 45 & 23.0 & \pm & 8.6 \\
\hline RU-2 & 2080 & \pm & 40 & & & & & & & 0 & \pm & 0 & & & \\
\hline
\end{tabular}

Table 6. 


\begin{tabular}{|c|c|c|c|c|c|}
\hline KNM-ER & Part of the specimen & Taxon & $\begin{array}{l}\text { Level } \\
\text { Feibel et al., } 1989\end{array}$ & $\begin{array}{l}\text { Level } \\
\text { This study }\end{array}$ & Constrained between (Ma) \\
\hline 1483 & Mandibular fragments & Homo sp. & $K B S-4 m$ & & 1.85-1.95 (between KBS Tuff and base Olduvai chron) \\
\hline 1481 & Lt. femur, partial tibia and fibula & Homo sp. & $K B S-12 m$ & KBS-15m & 1.95-1.98 (just ( $\max \sim 30 \mathrm{~cm}$ ) below base Olduvai chron) \\
\hline 1803 & Rt. mandibular body & P. boisei & $K B S-12 m$ & KBS-15m & 1.95-1.98 (just ( $\max \sim 30 \mathrm{~cm}$ ) below base Olduvai chron) \\
\hline 1469 & Lt. mandibular body & P. boisei & $K B S-13 m$ & & 1.95-1.98 (between base Olduvai chron and Pre-Olduvai event) \\
\hline 62000 & Partial cranium & Homo sp & & KBS-21m & 1.95-1.98 (1 m above Pre-Olduvai event) \\
\hline 1802 & Mandibular body & Homo sp. & GPC- & & 1.98-2.09 (between Pre-Olduvai event and age KNM-ER 1470) \\
\hline 3951 & Postcrania & Homo sp. & GPC- & & 1.98-2.09 (between Pre-Olduvai event and age KNM-ER 1470) \\
\hline 1473 & Rt. proximal humerus & Homo sp. & $K B S-25 m$ & & 1.98-2.09 (between Pre-Olduvai event and age KNM-ER 1470) \\
\hline 1475 & Rt. proximal femur & Homo sp. & $K B S-25 m$ & & 1.98-2.09 (between Pre-Olduvai event and age KNM-ER 1470) \\
\hline 1482 & Partial mandible & Homo sp. & $K B S-26 m$ & & 1.98-2.09 (between Pre-Olduvai event and age KNM-ER 1470) \\
\hline 1471 & Rt. proximal tibia & Homo sp. & $K B S-27 m$ & & 1.98-2.09 (between Pre-Olduvai event and age KNM-ER 1470) \\
\hline 1472 & Rt. Femur & Homo sp. & $K B S-30 m$ & & 1.98-2.09 (between Pre-Olduvai event and age KNM-ER 1470) \\
\hline 1801 & Lt. mandibular body & Homo sp. & $F-$ & & 1.98-2.09 (between Pre-Olduvai event and age KNM-ER 1470) \\
\hline 1474 & Vault fragment & Homo sp. & $K B S-32 m$ & & 1.98-2.09 (between Pre-Olduvai event and age KNM-ER 1470) \\
\hline 1470 & Cranium & Homo sp. & $K B S-36 m$ & KBS-41m & $2.03-2.09$ \\
\hline
\end{tabular}

Table 7. 


\begin{tabular}{|c|c|c|c|c|c|}
\hline Area 105 & Samples & $\begin{array}{c}\text { Stratigraphical } \\
\text { depth }(m)\end{array}$ & Latitude & Longitude & Remarks \\
\hline Section 13 & - & 31 & $44.310 ` \mathrm{~N}$ & 3621.680 'E & Top KBS Tuff \\
\hline Section 12 & - & 32 & $44.294 \mathrm{~N}$ & 3621.658 'E & \\
\hline \multirow[t]{12}{*}{$26-32 m$} & KS063 & 31.8 & & & \\
\hline & KS062 & 31.5 & & & \\
\hline & KS061 & 30.9 & & & \\
\hline & KS060 & 30.3 & & & \\
\hline & KS059 & 29.8 & & & \\
\hline & KS058 & 29 & & & \\
\hline & KS057 & 28 & & & \\
\hline & KS056 & 27.9 & & & \\
\hline & KS055 & 27.5 & & & \\
\hline & KS054 & 26.7 & & & \\
\hline & KS053 & 26.5 & & & \\
\hline & - & 26 & $44.291 \mathrm{~d}$ & 3621.652 'E & \\
\hline Section 11 & KS052 & 23.5 & $44.246{ }^{\prime} \mathrm{N}$ & 3621.604 'E & \\
\hline \multirow[t]{5}{*}{$21.5-24 \mathrm{~m}$} & KS051 & 23.2 & & & \\
\hline & KS050 & 23 & & & \\
\hline & KS049 & 22.7 & & & \\
\hline & KS048 & 22.5 & & & \\
\hline & - & 21.5 & $44.249{ }^{\prime} \mathrm{N}$ & 3621.602 'E & \\
\hline Section 10 & - & 23 & $44.251^{\circ} \mathrm{N}$ & 3621.605 'E & \\
\hline \multirow[t]{6}{*}{$21-23 m$} & KS047 & 22.1 & & & \\
\hline & KS046 & 22 & & & \\
\hline & KS045 & 21.75 & & & \\
\hline & KS044 & 21.5 & & & \\
\hline & KS043 & 21.3 & & & \\
\hline & - & 21 & $44.252^{`} \mathrm{~N}$ & 3621.605 ‘ $E$ & \\
\hline Section 9 & KS042 & 21.5 & & & \\
\hline \multirow[t]{6}{*}{$18-22.5 m$} & KS041 & 21 & $44.137{ }^{\prime} \mathrm{N}$ & 3621.666 'E & \\
\hline & KS040 & 20.5 & & & \\
\hline & KS039 & 20.4 & & & \\
\hline & KS038 & 19.4 & $44.142^{`} \mathrm{~N}$ & 3621.665 ‘ $E$ & \\
\hline & KS037 & 18.5 & & & \\
\hline & KS036 & 18 & & & \\
\hline Section 8 & - & 15.7 & $44.241^{\prime} \mathrm{N}$ & 3621.585 'E & Correlative bed \\
\hline Section 7 & KS035 & 17 & & & \\
\hline \multirow[t]{3}{*}{$14-17 m$} & KS034 & 16.5 & & & \\
\hline & KS033 & 16 & & & \\
\hline & KS032 & 15.1 & $44.235{ }^{\prime} \mathrm{N}$ & 3621.553 ‘E & \\
\hline Section 6 & KS031 & 15.4 & $44.230 ` \mathrm{~N}$ & 3621.516 'E & \\
\hline \multirow[t]{3}{*}{$12-16 m$} & KS030 & 14.6 & & & \\
\hline & KS029 & 13.7 & & & \\
\hline & KS028 & 13.3 & 44.226 'N & 3621.514 'E & \\
\hline
\end{tabular}




\begin{tabular}{|c|c|c|c|c|c|}
\hline Section 5 & KS027 & 12.7 & $44.2388^{\prime} \mathrm{N}$ & 3621.436 'E & \\
\hline $12-13 m$ & KS026 & 12 & “ & $“$ & \\
\hline Section 4 & KS025 & 11.7 & $44.210^{\circ} \mathrm{N}$ & 3621.407 'E & \\
\hline \multirow[t]{3}{*}{$10-12 m$} & KS024 & 11.4 & “ & “ & \\
\hline & KS023 & 10.9 & " & “ & \\
\hline & KS022 & 10.1 & $"$ & “ & \\
\hline Section 3 & & 10.5 & 44.186 'N & 3621.252 'E & GPC \\
\hline \multirow[t]{9}{*}{$6-10.5 m$} & KS014 & 10 & & & \\
\hline & KS015 & 9.7 & & & \\
\hline & KS016 & 9.1 & 44.186 'N & 3621.251 'E & \\
\hline & KS017 & 8.8 & & & \\
\hline & KS018 & 8.5 & & & \\
\hline & KS019 & 7.9 & & & \\
\hline & KS020 & 7.5 & & & \\
\hline & KS021 & 6.9 & $44.1866^{\circ} \mathrm{N}$ & 3621.250 'E & \\
\hline & - & 6 & $44.186{ }^{\prime} \mathrm{N}$ & 3621.249 'E & \\
\hline Section 2 & KS013 & 6.4 & $44.297 \mathrm{~N}$ & 3621.076 'E & \\
\hline \multirow[t]{4}{*}{$4.5-6 m$} & KS012 & 6.1 & “ & " & \\
\hline & KS011 & 5.5 & " & $“$ & \\
\hline & KS010 & 5.1 & “ & “ & \\
\hline & KS009 & 4.4 & $"$ & “ & \\
\hline Section 1 & KS008 & 4.3 & $44.3666^{\circ} \mathrm{N}$ & 3620.946 'E & \\
\hline \multirow[t]{9}{*}{$0-4.5 m$} & KS007 & 3.8 & “ & " & \\
\hline & KS006 & 3.2 & $"$ & " & \\
\hline & KS005b & 2.9 & $"$ & $"$ & \\
\hline & KS005a & 2.7 & " & “ & \\
\hline & - & 2 & $44.361 \mathrm{~N}$ & 3620.950 ‘E & \\
\hline & KS004 & 1.9 & & & \\
\hline & KS003 & 1.4 & $44.360 ` \mathrm{~N}$ & 3620.956 ‘E & \\
\hline & KS002 & 0.8 & & & \\
\hline & KS001 & 0.1 & 44.359 ' N & 3620.956 'E & \\
\hline
\end{tabular}

Table A.1. 


\begin{tabular}{|c|c|c|c|c|c|}
\hline Area 131 & Samples & $\begin{array}{l}\text { Stratigraphical } \\
\text { depth }(m)\end{array}$ & Latitude & Longitude & Remarks \\
\hline Section 16 & - & 46.0 & 49.542 'N & 3623.878 ' $E$ & Base KBS Tuff \\
\hline \multirow[t]{21}{*}{$36-46.5 \mathrm{~m}$} & KR082 & 45.4 & & & \\
\hline & - & 45.0 & $49.541 \cdot N$ & 3623.878 ' $E$ & \\
\hline & KR083 & 44.6 & “ & “ & \\
\hline & KR084 & 44.2 & “ & “ & \\
\hline & - & 44.0 & “ & “ & \\
\hline & KR085 & 43.7 & & & \\
\hline & KR086 & 43.4 & & & \\
\hline & - & 43.0 & 49.539 ' N & 3623.877 ' $E$ & \\
\hline & KR087 & 42.5 & & & \\
\hline & KR088 & 42.0 & 49.540 'N & 3623.876 ' $E$ & \\
\hline & KR089 & 41.5 & & & \\
\hline & - & 41.0 & $49.541 \cdot N$ & 3623.875 ' $E$ & \\
\hline & KR090 & 40.6 & & & \\
\hline & KR091 & 40.4 & & & \\
\hline & KR092 & 40.1 & & & \\
\hline & - & 40.0 & 49.536 ' N & 3623.873 ' $E$ & \\
\hline & KR093 & 39.0 & 49.535 ' N & 3623.872 ' $E$ & \\
\hline & KR094 & 38.8 & & & \\
\hline & KR095 & 38.3 & & & \\
\hline & - & 38.0 & 49.535 'N & 3623.870 ' $E$ & \\
\hline & - & 36.0 & $49.5355^{\prime} \mathrm{N}$ & 3623.868 ' $E$ & Correlating Sandstone \\
\hline Section 15 & KR081 & 35.4 & 49.537 ' N & 3623.855 ' $E$ & \\
\hline \multirow[t]{5}{*}{$33-36.5 m$} & KR080 & 35.0 & " & " & \\
\hline & KR079 & 34.5 & $"$ & $"$ & \\
\hline & KR078 & 34.0 & $"$ & $"$ & \\
\hline & KR076 & 33.5 & 49.535 ' N & 3623.856 ' $E$ & \\
\hline & KR075 & 33.3 & " & " & \\
\hline Section 14 & KR074 & 32.0 & $49.5333^{\prime} \mathrm{N}$ & 3623.849 ' $E$ & \\
\hline Section 13 & KR073 & 35.1 & $49.529^{\prime} \mathrm{N}$ & 3623.837 ' $E$ & \\
\hline \multirow[t]{9}{*}{$31.5-36 \mathrm{~m}$} & KR072 & 35.0 & " & " & \\
\hline & KR071 & 34.2 & 49.530 ' N & 3623.837 ' $E$ & \\
\hline & KR070 & 33.6 & " & " & \\
\hline & KR069 & 33.5 & $49.531 \cdot N$ & 3623.837 ' $E$ & \\
\hline & KR068 & 33.0 & " & " & \\
\hline & KR067 & 32.7 & $"$ & $"$ & \\
\hline & KR066 & 32.5 & " & " & \\
\hline & KR065 & 32.4 & 49.532 ' N & 3623.834 ' $E$ & \\
\hline & KR064 & 31.5 & & & \\
\hline Section 12 & - & 32.0 & 49.571 ' N & 3623.83 ' $E$ & LCC conglomerate \\
\hline $30-36 m$ & - & 36.0 & " & " & Correlating Sandstone \\
\hline Section 11 & KR063 & 30.2 & 49.635 ' N & 3623.737 ' $E$ & \\
\hline \multirow[t]{5}{*}{$37-31 m$} & KR062 & 30.0 & " & " & \\
\hline & KR061 & 29.2 & " & " & \\
\hline & KR060 & 28.2 & 49.635 ' N & 3623.734 ' $E$ & \\
\hline & KR059a & 27.3 & " & " & \\
\hline & KR059b & 27.2 & $"$ & $"$ & \\
\hline
\end{tabular}




\begin{tabular}{|c|c|c|c|c|}
\hline Section 10 & KR058 & 27.0 & $49.638^{\prime} \mathrm{N}$ & 3623.725 'E \\
\hline \multirow[t]{3}{*}{$25-27 m$} & KR057 & 26.2 & " & " \\
\hline & KR056 & 25.8 & $"$ & $"$ \\
\hline & KR055 & 25.5 & $"$ & $"$ \\
\hline Section 9 & KR054 & 24.4 & 49.608 ' N & 3623.654 ' $E$ \\
\hline $24-25 m$ & KR053 & 23.9 & $"$ & $"$ \\
\hline Section 8 & KR052 & 23.7 & $49.725^{\prime} \mathrm{N}$ & 3623.511 ' $E$ \\
\hline \multirow[t]{2}{*}{$22-24 m$} & KR051 & 23.4 & $"$ & $"$ \\
\hline & KR050 & 23.1 & $"$ & $"$ \\
\hline Section 7 & KR049 & 21.5 & $49.734^{\prime} \mathrm{N}$ & 3623.486 ' $E$ \\
\hline \multirow[t]{10}{*}{$17-22 m$} & KR048 & 20.5 & $49.740^{\prime} \mathrm{N}$ & 3623.486 ' $E$ \\
\hline & KR047 & 20.0 & $"$ & $"$ \\
\hline & KR046 & 19.5 & $"$ & $"$ \\
\hline & KR045 & 19.3 & $"$ & $"$ \\
\hline & KR044 & 19.0 & & \\
\hline & KR043 & 18.8 & 49.740 ' N & 3623.485 ' $E$ \\
\hline & KR042 & 18.3 & " & " \\
\hline & KR041 & 17.7 & $"$ & $"$ \\
\hline & KR040 & 17.3 & $"$ & $"$ \\
\hline & KR039 & 17.0 & 49.742 'N & 3623.485 ' $E$ \\
\hline Section 6 & KR038 & 15.8 & $49.803^{\prime} \mathrm{N}$ & 3623.462 ' $E$ \\
\hline \multirow[t]{7}{*}{$12-17.5 m$} & KR037 & 15.6 & " & " \\
\hline & KR036 & 15.4 & " & " \\
\hline & KR035 & 14.5 & $49.803^{\prime} \mathrm{N}$ & 3623.461 ' $E$ \\
\hline & KR034 & 14.0 & 49.804 ' N & 3623.460 ' $E$ \\
\hline & KR033 & 13.6 & " & " \\
\hline & KR032 & 13.0 & $49.804^{\prime} \mathrm{N}$ & 3623.46 ' $E$ \\
\hline & KR031 & 12.6 & $49.803^{\prime} \mathrm{N}$ & 3623.46 ' $E$ \\
\hline Section 5 & KR030 & 12.1 & $49.800^{\prime} \mathrm{N}$ & 3623.451 ' $E$ \\
\hline \multirow[t]{3}{*}{$10.5-13 m$} & KR029 & 11.9 & $"$ & $"$ \\
\hline & KR028 & 11.5 & $"$ & $"$ \\
\hline & KR027 & 11.0 & $"$ & $"$ \\
\hline Section 4 & KR026 & 10.3 & & \\
\hline \multirow[t]{11}{*}{$8-10.5 m$} & KR025 & 10.4 & & \\
\hline & KR024 & 10.2 & & \\
\hline & - & 10.0 & $49.772^{\prime} \mathrm{N}$ & 3623.388 ' $E$ \\
\hline & KR023 & 9.9 & & \\
\hline & KR022 & 9.8 & & \\
\hline & KR021 & 9.5 & & \\
\hline & KR020 & 9.25 & & \\
\hline & KR019 & 9.0 & $49.774^{\prime} \mathrm{N}$ & 3623.389 ' $E$ \\
\hline & KR018 & 8.75 & & \\
\hline & KR017 & 8.6 & & \\
\hline & KR016 & 8.4 & & \\
\hline Section 3 & KR015 & 8.2 & & \\
\hline $7-8.5 m$ & KR014 & 8.0 & 49.779 ' N & 3623.377 ' $E$ \\
\hline
\end{tabular}




\begin{tabular}{|c|c|c|c|c|c|}
\hline & KR013 & 7.8 & & & \\
\hline & KR012 & 7.6 & & & \\
\hline Section 2 & KR008 & 6.8 & 49.814 ' N & 3623.338 ' $E$ & \\
\hline \multirow[t]{6}{*}{$4.5-7 m$} & KR007 & 6.5 & $"$ & $"$ & \\
\hline & KR006 & 6.25 & $"$ & $"$ & \\
\hline & KR005 & 6.0 & $"$ & " & \\
\hline & KR011 & 5.5 & 49.805 ' $N$ & 3623.348 ' $E$ & \\
\hline & KR010 & 5.1 & $"$ & $"$ & \\
\hline & KR009 & 4.8 & $"$ & $"$ & \\
\hline Section 1 & - & 7.0 & 49.790 ' N & 3623.327 ' $E$ & \\
\hline \multirow[t]{10}{*}{$0-7 m$} & - & 6.0 & 49.790 'N & 3623.326 ' $E$ & \multirow{10}{*}{ KNMER-1470 } \\
\hline & - & 5.0 & 49.790 ' N & 3623.324 ' $E$ & \\
\hline & - & 4.0 & 49.793 ' $N$ & 3623.324 ' $E$ & \\
\hline & - & 3.0 & 49.794 ' $N$ & 3623.323 ' $E$ & \\
\hline & KR004 & 2.9 & & & \\
\hline & - & 2.0 & 49.796 ' $N$ & $3623.323^{\prime} \mathrm{E}$ & \\
\hline & KR003 & 1.9 & " & $"$ & \\
\hline & - & 1.0 & 49.797 ' N & 3623.323 ' $E$ & \\
\hline & KR002 & 0.2 & & & \\
\hline & KR001 & 0 & 49.798 ' $N$ & 3623.324 ' $E$ & \\
\hline
\end{tabular}

\section{Table A.2.}

